\title{
Modeling Vertical and Horizontal Solute Transport for the Weldon Spring Site Remedial Action Project
}

by $D$. Tomasko

Environmental Assessment and Information Sciences Division, Argonne National Laboratory, 9700 South Cass Avenue, Argonne, Illinois 60439

November 1992

Work sponsored by United States Department of Energy, Weldon Spring Site Remedial Action Project 


\section{CONTENTS}

NOTATION $\ldots \ldots \ldots \ldots \ldots \ldots \ldots \ldots \ldots \ldots \ldots \ldots \ldots \ldots \ldots \ldots \ldots \ldots \ldots \ldots$

ABSTRACT $\ldots \ldots \ldots \ldots \ldots \ldots \ldots \ldots \ldots \ldots \ldots \ldots \ldots \ldots \ldots \ldots \ldots \ldots \ldots$

1 INTRODUCTION $\ldots \ldots \ldots \ldots \ldots \ldots \ldots \ldots \ldots \ldots \ldots \ldots \ldots \ldots \ldots \ldots \ldots$

2 METHODOLOGY $\ldots \ldots \ldots \ldots \ldots \ldots \ldots \ldots \ldots \ldots \ldots \ldots \ldots \ldots \ldots \ldots$

2.1 Vadose Zone .............................. 7

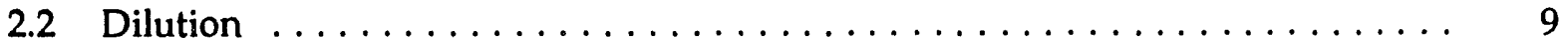

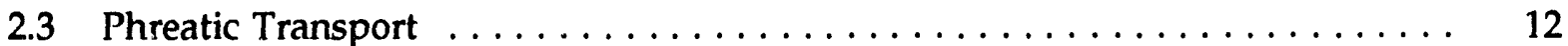

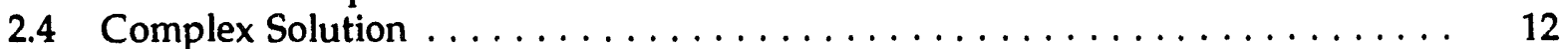

2.5 Models .................................. 17

3 CAlCUlations $\ldots \ldots \ldots \ldots \ldots \ldots \ldots \ldots \ldots \ldots \ldots \ldots \ldots \ldots$

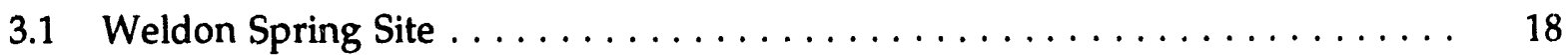

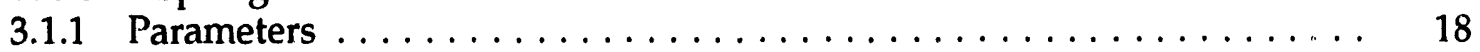

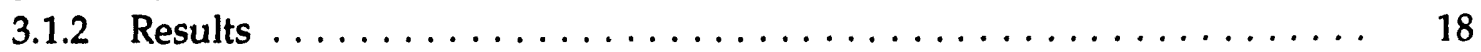

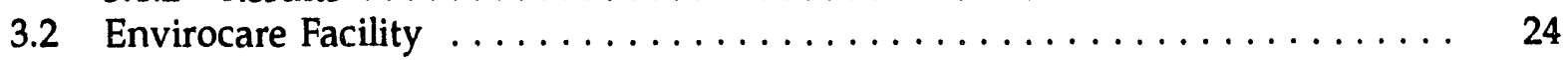

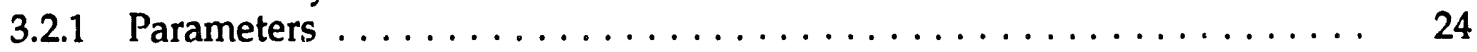

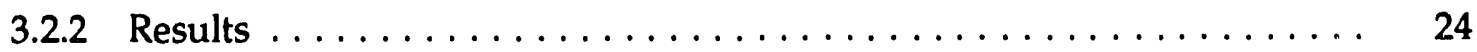

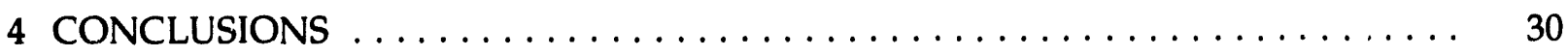

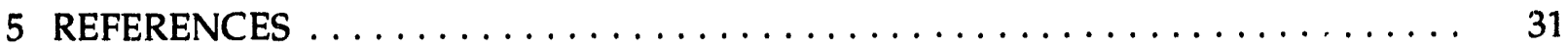

\section{FIGURES}

1 Location of the Weldon Spring Site $\ldots \ldots \ldots \ldots \ldots \ldots \ldots \ldots \ldots \ldots \ldots \ldots \ldots$

2 Fate and Transport Processes $\ldots \ldots \ldots \ldots \ldots \ldots \ldots \ldots \ldots \ldots \ldots \ldots \ldots$

3 Approximate Contaminant Pulse Shapes $\ldots \ldots \ldots \ldots \ldots \ldots \ldots \ldots$

4 Elemental Control Volume for Dilution Model . . . . . . . . . . . . . . . . 11

5 Contaminant Breakthrough Curves for the Vadose Zone at the Weldon Spring Site: Retardation $=1$ and $5 \ldots \ldots \ldots \ldots \ldots$

6 Contaminant Breakthrough Curves for the Vadose Zone at the Weldon Spring Site: Retardation $=100$ 


\section{FIGURES (Cont.)}

7 Contaminant Breakthrough Curves for the Phreatic Zone at the Weldon Spring Site: Retardation $=1$ and 5;

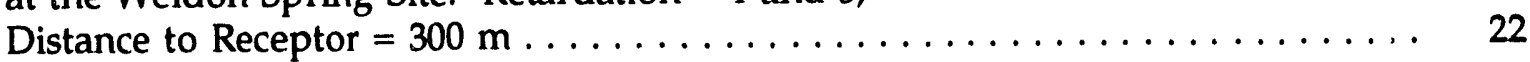

8 Contaminant Breakthrough Curves for the Phreatic Zone at the Weldon Spring Site: Retardation = 100;

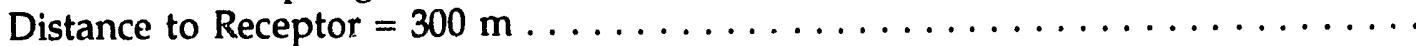

9 Comparison of Simple and Complex Models for the Weldon

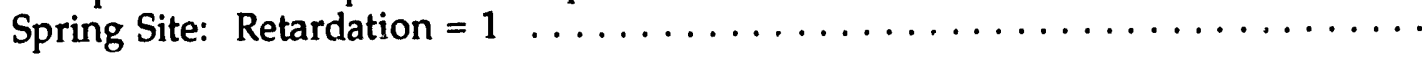

10 Comparison of Simple and Complex Models for the Weldon Spring Site: Retardation $=100$.

11 Contaminant Breakthrough Curves for the Vadose Zone at the Envirocare Facility: Retardation $=1$ and 5 .

12 Contaminant Breakthrough Curves for the Vadose Zone at the Envirocare Facility: Retardation $=100$

13 Contaminant Breakthrough Curves for the Phreatic Zone at the Envirocare Facility: Retardation $=1$ and 5;

Distance to Receptor $=1,600 \mathrm{~m}$

14 Contaminant Breakthrough Curves for the Phreatic Zone at the Envirocare Facility: Retardation $=100$; Distance

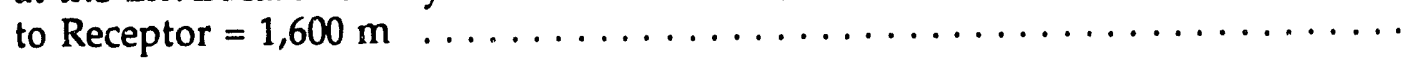

15 Comparison of Simple and Complex Models at the Envirocare

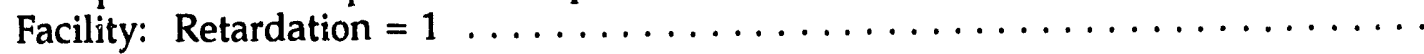

16 Comparison of Simple and Complex Models at the Envirocare Facility: Retardation $=5 \ldots \ldots \ldots \ldots \ldots \ldots \ldots \ldots \ldots \ldots \ldots$

\section{TABLES}

1 Summary of Disposal Cell Failure Calculations for the Weldon Spring Site: One-Dimensional Vadose Zone $\ldots \ldots \ldots \ldots \ldots \ldots \ldots \ldots$

2 Summary of Disposal Cell Failure Calculations for the Envirocare Facility: One-Dimensional Vadose Zone 


\title{
NOTATION
}

The following is a list of the acronyms, initialisms, and abbreviations (including units of measure) used in this document. Some acronyms used in tables or equations only are defined in the respective tables or equations.

\section{ACRONYMS, INITIALISMS, AND ABBREVIATIONS}

\author{
DOE \\ EPA \\ U.S. Department of Energy \\ U.S. Environmental Protection Agency
}

\section{UNITS OF MEASURE}

$\begin{array}{ll}\mathrm{cm} & \text { centimeter } \\ \mathrm{d} & \text { day } \\ \mathrm{ft} & \text { foot } \\ \text { in. } & \text { inch } \\ \text { ha } & \text { hectare } \\ \mathrm{km} & \text { kilometer }\end{array}$

$\begin{array}{ll}\mathrm{m} & \text { meter } \\ \mathrm{mi} & \text { mile } \\ \mathrm{mi}^{2} & \text { square mile } \\ \mathrm{s} & \text { second } \\ \mathrm{yr} & \text { year }\end{array}$




\title{
MODELING VERTICAL AND HORIZONTAL SOLUTE TRANSPORT FOR THE WELDON SPRING SITE REMEDIAL ACTION PROJECT
}

by

D. Tomasko

\begin{abstract}
This technical memorandum presents a one-dimensional model to simulate the transport of a contaminant that originates as a liquid release, moves vertically downward through a vadose zone, mixes with initially clean groundwater in an unconfined aquifer, and ends at a downgradient extraction well. Vertical and horizontal segments of the contaminant pathway are coupled by assuming that the breakthrough curve of the contaminant at the water table acts as a contaminant source for the unconfined aquifer. For simplicity, this source is assumed to be a time-shifted unit square wave having an amplitude equal to the peak breakthrough concentration at the water table and a duration equal to the full width of the breakthrough curve at the half-maximum concentration value. The effects of dilution at the water-table interface are evaluated with a simple mass-balance equation. Comparing the model results for the chemical plant area of the Weldon Spring site near St. Louis, Missouri, and the Envirocare facility located near Salt Lake City, Utah, with those obtained from a solution formulated with the real and imaginary parts of a Fourier series in Laplace space indicates that the model provides a conservative estimate of the contaminant breakthrough curve at the receptor.
\end{abstract}

\section{INTRODUCTION}

The Weldon Spring site is located in St. Charles County, Missouri, about $48 \mathrm{~km}$ (30 mi) west of St. Louis (Figure 1). The site became contaminated as a result of processing and disposal activities that took place from the 1940s through the 1960s, and it is listed on the National Priorities List of the U.S. Environmental Protection Agency (EPA). The U.S. Department of Energy (DOE) is responsible for cleanup activities at the Weldon Spring site under its Environmental Restoration and Waste Management Program.

The Weldon Spring site consists of two noncontiguous areas: an 88-ha (217-acre) chemical plant area and a 3.6-ha (9-acre) limestone quarry. The chemical plant area is about $3.2 \mathrm{~km}(2 \mathrm{mi})$ southwest of the junction of Missouri (State) Route 94 and U.S. Route 40/61, and the quarry is about $6.4 \mathrm{~km}(4 \mathrm{mi})$ south-southwest of the chemical plant area. Both locations are accessible from State Route 94 and are fenced and closed to the public. Explosives were 


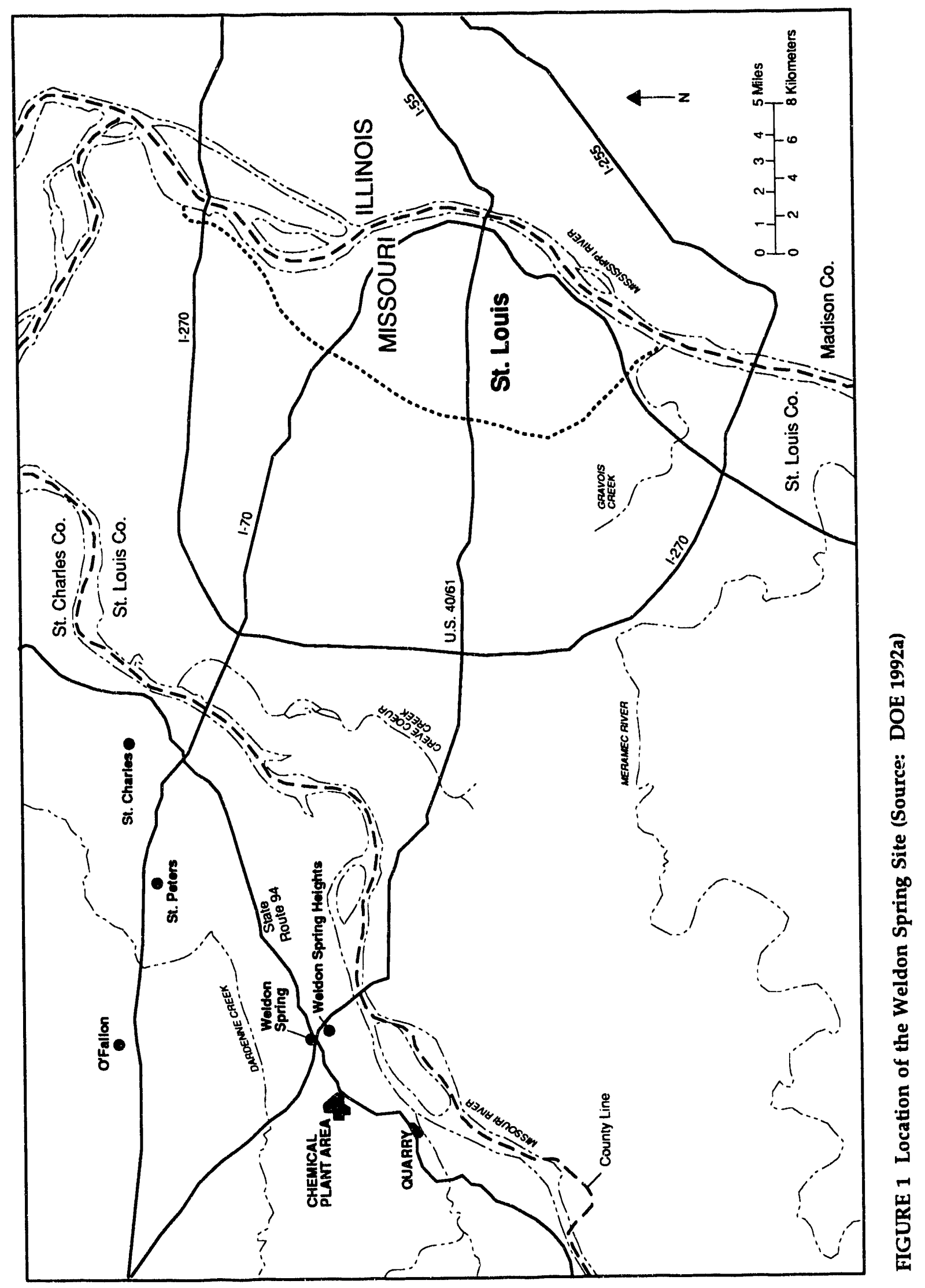


produced at the chemical plant during the 1940s, and uranium and thorium materials were processed during the 1950s and 1960s. During the latter operational period, waste slurries at the chemical plant area were piped to four retention ponds, referred to as raffinate pits; various solid wastes (i.e., process residues ard decontamination material that included soil, rubble, metal debris, and equipment) were disposed of in the quarry between 1942 and 1969.

This report presents the development and assessment of an analytical model for evaluating the fate and transport of contaminants released to the environment in the unlikely event of disposal cell failure with no corrective response. The conservative nature of the model is assessed by using site-specific parameters for the Weldon Spring site and the Envirocare facility near Clive, Utah, an alternative location for off-site waste disposal. Evaluating the concentration of a groundwater contaminant downgradient of a surface source frequently requires complex calculations. The analytical model presented herein is a simple, onedimensional model that calculates the breakthrough time and peak concentration of a contaminant at a receptor located downgradient of a surface source. The model is demonstrated for a hypothetical disposal cell failure that results in the release of a suite of contaminants to the hydrological environment at the chemical plant area of the Weldon Spring site; additional assessment of the model is provided by a second set of calculations for a similar hypothetical incident at the Envirocare facility.

In both sets of calculations, the contaminants are assumed to follow a path that originates at the bottom of the failed disposal cell, moves vertically downward through an unsaturated (vadose) zone, moves horizontally through an unconfined (phreatic) aquifer, and ultimately ends at a receptor at a downgradient extraction well. In a heterogeneous, anisotropic system, this overall process can be very complex and difficult to model precisely. With appropriate simplifying assumptions, the process can be conservatively simulated by using two one-dimensional transport calculations coupled at the vadose/phreatic interface and an associated dilution calculation.

This report details the development of a one-dimensional model that couples vertical and horizontal transport. The model assumes that the contaminant breakthrough curve at the water table can be represented with a time-shifted unit step function having an amplitude equal to the peak breakthrough concentration and a duration equal to the full width of the breakthrough curve at the half-maximum concentration value, rather than a combination of exponential and complementary error functions (Tomasko 1989, 1990).

A comparison of the model-predicted results with those obtained with a more realistic solution (formulated from the real and imaginary parts of a Fourier series in Laplace space) indicates that the model provides a conservative estimate of the contaminant breakthrough curve at the location of the receptor. 


\section{METHODOLOGY}

The proposed model divides the overall transport process into three phases: transport through the unsaturated zone; mixing directly below the source at the interface between the vertically moving contaminated water in the vadose zone and initially clean, horizontally moving groundwater in the phreatic zone; and lateral transport through the saturated zone (Figure 2).

For modeling purposes, the physical processes shown in Figure 2 were simplified to three calculations: two one-dimensional transport calculations (vadose and phreatic zones) and a dilution calculation at the water-table interface. The one-dimensional calculations provide a conservative estimate of the process because transverse spreading is assumed to be negligible. Figure 3 shows the approximate time-dependent shapes of the contaminant distribution assumed for various stages of development. At the release point, the contaminant pulse is assumed to behave as a step function, i.e., the contaminant concentration exiting the failed disposal cell has a constant unit concentration for a specified duration, after which time the concentration returns to zero.

After entering the vadose zone, the contaminated groundwater moves primarily in a vertical direction under the influence of gravity. Eventually, the contaminant reaches the water table. At this point, dispersion along the flow path has changed the shape of the pulse of

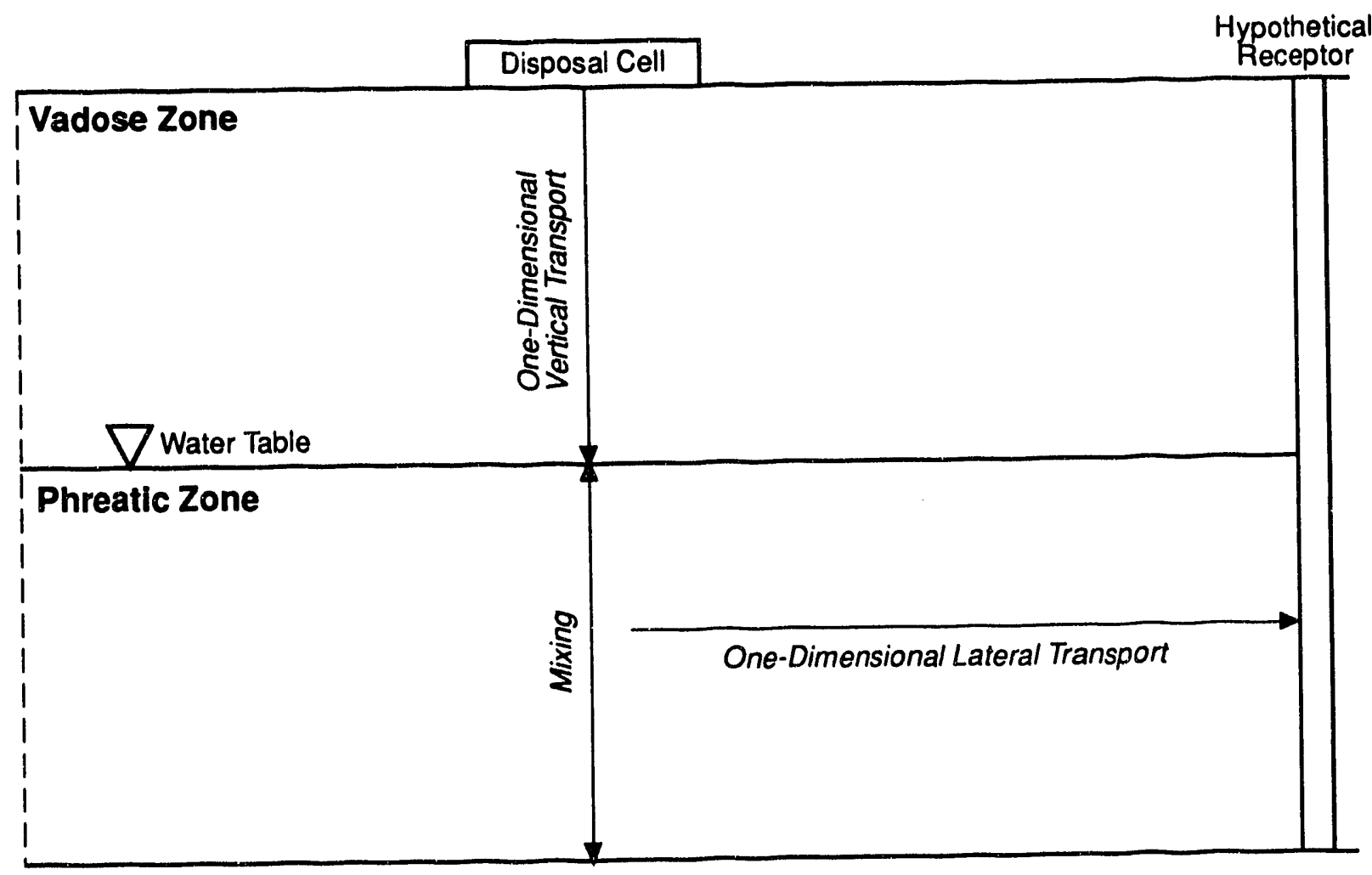

FIGURE 2 Fate and Transport Processes 
contamination, as illustrated in Figure 3. The peak concentration achieved at the interface, $\mathrm{C}_{\mathrm{vmax}}$, can be less than the value at the release point, the pulse duration can be significantly greater than the leachate emptying time, and the shape of the leading edge and tail of the contaminant pulse can be distorted by longitudinal spreading.

Following intersection with the unconfined aquifer system, the contaminated groundwater from the vadose zone mixes with uncontaminated groundwater in the aquifer. Assuming, for simplicity, that the groundwater is initially uncontaminated permits a clear indication of potential impacts from cell failure. This process can be very complex; however, for simplicity, mixing is assumed to be instantaneous and homogeneous across the thickness of the saturated zone. The resulting contaminant pulse shape is thus the same after mixing as at the water-table interface, except for a constant dilution factor.

Once mixed, the contaminant is assumed to be transported laterally to a receptor by the natural flow system; the infiltrating leachate is assumed to have a negligible effect on the existing potentiometric surface. Under actual conditions, the shape of the source function for lateral transport is the shape of the contaminant pulse at the water-table interface modified by mixing. For simplicity, this function is also assumed to be a second step function having a height equal to the peak concentration in the vadose zone at the water-table interface and a duration equal to the full width of the contaminant pulse in the vadose zone at the interface when the contaminant concentration values are at half of their maximum value, i.e., the full width at halfmaximum (Figure 3). As a convenience, the lateral transport calculation is assumed to begin at a time equal to zero. This assumption requires shifting the second step function source by a time, $t_{\text {shift }}$ equal to that required for the concentration in the vadose zone to achieve its first half- .. maximum value (Figure 3 ).

At the receptor, the shape of the contaminant pulse is again broadened and reduced because of dispersion along the flow path. A maximum concentration, $\mathrm{C}_{\text {smax }}$, is achieved in a time equal to $t_{\text {peak }}$ (Figure 3 ).

The time and value of the peak concentration at the receptor can be related to the initial time of the disposal cell failure and the initial leachate concentration by using the following relationships:

$$
t_{\text {receptor }}=t_{\text {peak }}+t_{\text {shift }}
$$

and

$$
\mathrm{C}_{\text {receptormax }}=\mathrm{C}_{\text {vmax }} \frac{\mathrm{C}_{\text {smax }}}{\text { dilution factor }}
$$




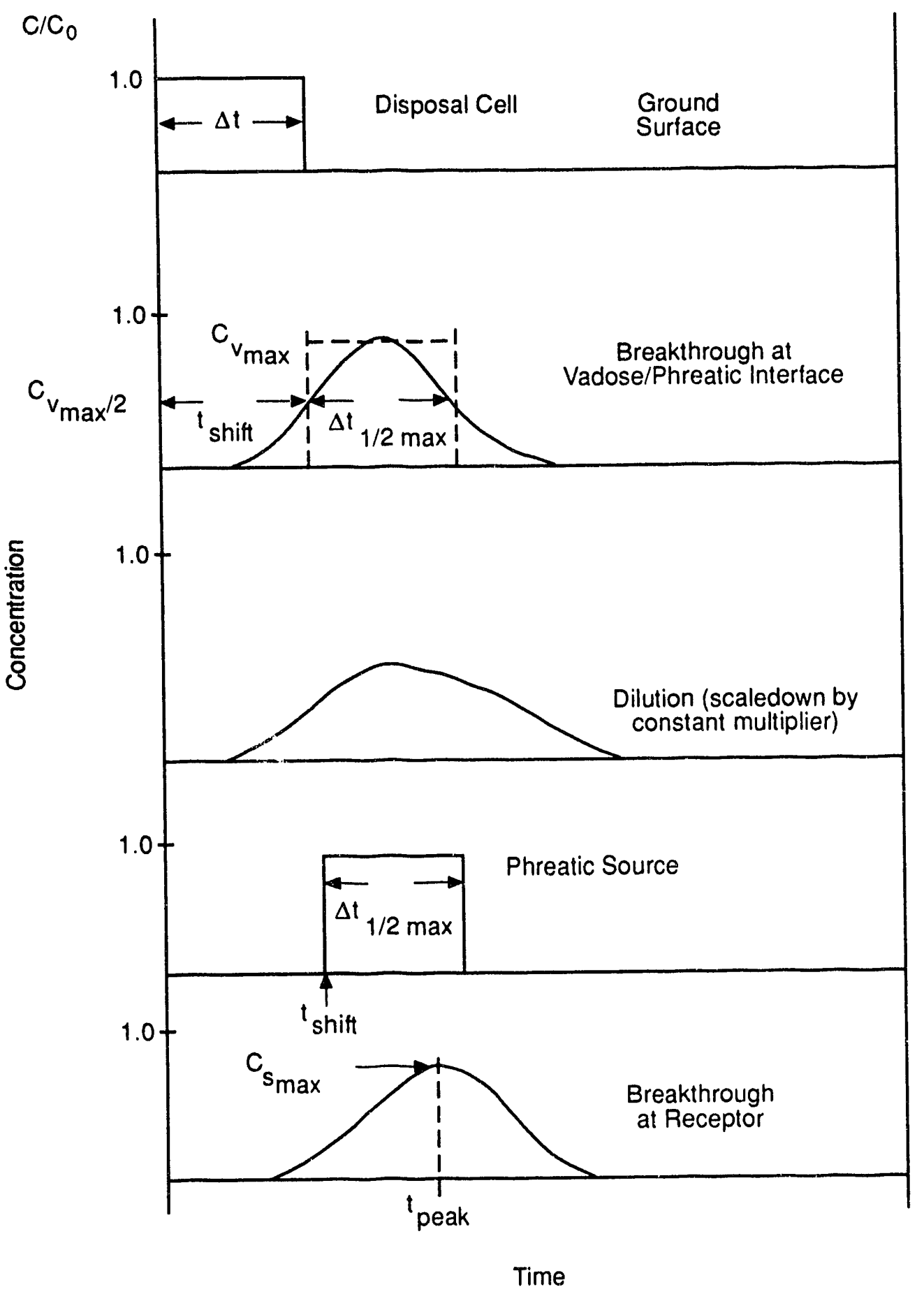

FIGURE 3 Approximate Contaminant Pulse Shapes 


\subsection{VADOSE ZONE}

Contaminant transport through the vadose zone is modeled conservatively as a onedimensional, vertical process in which the infiltration velocity of the solute is assumed to be equal to the saturated hydraulic conductivity of the matrix material. The governing equation is assumed to be the one-dimensional, advection-dispersion equation given by Freeze and Cherry (1979) as:

$$
\frac{\partial C}{\partial t}+\frac{V}{R} \frac{\partial C}{\partial Z}=\frac{D}{R} \frac{\partial^{2} C}{\partial Z^{2}}
$$

where:

$$
\begin{aligned}
C= & \text { contaminant concentration }\left(M / L^{3}\right) ; \\
D= & \text { dispersion coefficient }\left(L^{2} / t\right) ; \\
R= & \begin{aligned}
& \text { retardation coefficient given by the expression } R=1+\rho_{b} K_{d} / \phi, \\
& \text { where } K_{d}=\text { distribution coefficient }\left(L^{3} / M\right) \text { and } \rho_{b}=\text { bulk density } \\
&\left(M / L^{3}\right) ;
\end{aligned} \\
t= & \text { time }(t) ; \\
V= & \text { actual groundwater velocity: } V_{d} / \phi(L / t) \text {, where } V_{d}=\text { Darcy } \\
& \text { velocity }(L / t) \text {, and } \phi=\text { porosity of the porous medium }\left(L^{3} / L^{3}\right) ; \text { and } \\
Z= & \text { spatial coordinate in the vertical direction }(L) .
\end{aligned}
$$

(Units are represented by generic terms for mass, length, and time [M, L, and $t]$.)

The dispersion coefficient, $D$, in Equation 3 is assumed to follow the functional form presented by Bear (1972):

$$
D=\alpha V
$$

where $\alpha=$ dispersivity (L). Diffusional effects are assumed to be negligible.

Dispersivity in Equation 4 is assumed to be scale dependent (Lallemand-Barrès and Peaudecerf 1978), i.e.,

$$
\alpha=0.1 \mathrm{~L}
$$

where $L$ is the separation distance between the origin of the source $(Z=0)$ and the point of interest (water table). 
Equation 3 was selected to represent the transport process on the basis of the following assumptions: lateral transport could be neglected; the seepage velocity (rate of infiltration) of the contaminant through the vadose zone could be approximated conservatively by using the saturated hydraulic conductivity of the porous medium; the seepage velocity is independent of time and space; the porous medium is homogeneous and isotropic; the contaminant is nondegradable, nonreactive, and nondecaying (or the half-life of the radionuclide is much longer than the transit time from the source to the receptor); and any sorption processes along the path can be represented with a linear isotherm (sorption processes are fast and reversible, i.e., the $K_{d}$ approximation).

For a simple square-wave source such as that assumed for calculational simplicity at the point of contaminant release, the concentration at $Z=0$ is $C_{0}$ and remains so until a time equal to $\Delta t$, when the concentration returns to zero. This function can be described with the following expression from Hildebrand (1976):

$$
\frac{C}{C_{0}}=U(t-0)-U(t-\Delta t)
$$

where $U$ is the unit function.

Applying the Laplace transform method (Kreyszig 1967) to Equations 3 and 6, assuming that the initial concentration of the solute is zero for all $\mathrm{Z}$ and that the concentration goes to zero as $\mathrm{Z}$ approaches infinity for all time, results in the following equation in Laplace space:

$$
\frac{\bar{C}}{C_{0}}=\frac{1}{S}\left(1-e^{-\Delta t s}\right) e^{\frac{v z}{2 D}} e^{-\sqrt{\frac{v^{2} z^{2}}{4 D^{2}}+\frac{S Z^{2} R}{D}}}
$$

Equation 7 can be inverted termwise with the following relationship (Ditkin and Prudnikov 1967):

$$
L^{-1}\left[\frac{e^{-\sqrt{A(B+S)}}}{S}\right]=\frac{1}{2}\left[e^{-\sqrt{A B}} \operatorname{ERFC}\left(\frac{1}{2} \sqrt{\frac{A}{t}}-\sqrt{B t}\right)+e^{\sqrt{A B}} \operatorname{ERFC}\left(\frac{1}{2} \sqrt{\frac{A}{t}}+\sqrt{B t}\right)\right]
$$

where ERFC is the complementary error function given by Hildebrand (1976) as:

$$
\operatorname{ERFC}(\gamma)=1-\operatorname{ERF}(\gamma)=1-\frac{2}{\sqrt{\pi}} \int_{0}^{\gamma} e^{-\lambda^{2}} d \lambda
$$


and the following shift identity for Laplace transforms (Hildebrand 1976):

$$
e^{-\Delta t S_{f}(S)}=L[f(t-\Delta t) H(t-\Delta t)]
$$

where $\mathrm{H}$ is the Heaviside function (Hildebrand 1976) such that:

$$
H(t-\Delta t)=0 \text { for } t<\Delta t
$$

and

$$
H(t-\Delta t)=1 \text { for } t \geq \Delta t
$$

Inverting Equation 7 yields the following:

$$
\begin{aligned}
\frac{C}{C_{0}}= & \frac{1}{2}\left[\operatorname{ERFC}\left(\frac{Z R-V t}{2 \sqrt{D R t}}\right)+e^{\frac{V Z}{D}} \operatorname{ERFC}\left(\frac{Z R+V t}{2 \sqrt{D R t}}\right)\right] \\
& -\frac{1}{2} H(t-\Delta t)\left\{\operatorname{ERFC}\left[\frac{Z R-V(t-\Delta t)}{2 \sqrt{D R(t-\Delta t)}}\right]+e^{\frac{V Z}{D}} \operatorname{ERFC}\left[\frac{Z R+V(t-\Delta t)}{2 \sqrt{D R(t-\Delta t)}}\right]\right\}
\end{aligned}
$$

\subsection{DILUTION}

In the event of a disposal cell failure, leachate generated in a disposal cell is assumed to migrate vertically downward toward an underlying unconfined water-table aquifer. Eventually, the contaminated groundwater in the unsaturated zone would mix with water in the saturated zone. Transport is then assumed to proceed laterally consistent with natural flow.

The ratio of the contaminant concentrations in the saturated zone to those in the unsaturated groundwater can be defined as the dilution for the process, $D_{1}$. This dilution can be expressed by the following relationship (EPA 1989), which assumes that mixing across the thickness of the unconfined aquifer is instantaneous and homogeneous:

$$
D_{1}=\frac{Q_{v}}{Q_{h}+Q_{v}}
$$

where:

$Q_{v}=$ volumetric flux in the vertical direction in the vadose zone, and

$\mathrm{Q}_{\mathrm{h}}=$ volumetric flux in the horizontal direction in the phreatic zone. 
The vertical volumetric flux of Equation $14, Q_{v}$, can be written as follows for the rectangular control volume shown in Figure 4:

$$
Q_{v}=I A_{v} \phi_{v}=I X_{L} W \phi_{v}
$$

where:

$$
I=\text { infiltration rate }(\mathrm{L} / \mathrm{t}) \text {, }
$$

$X_{L}=$ length of the control volume parallel to the direction of groundwater flow (L),

$W=$ transverse width of the control volume $(L)$, and

$\phi_{v}=$ effective porosity of the vadose zone $\left(L^{3} / L^{3}\right)$.

For analysis, $X_{L}$ is assumed to be equal to the length of the failed disposal cell in a direction parallel to that of natural groundwater flow.

The horizontal volumetric flux, $\mathrm{Q}_{\mathrm{h}}$, of Equation 14 can be written as:

$$
Q_{h}=V_{s} A_{e}=V_{d} A_{t}
$$

where:

$A_{e}=$ effective cross-sectional area of the saturated aquifer $\left[A_{t} \times \phi_{s}\left(L^{2}\right)\right] ;$

$A_{t}=$ total cross-sectional area of the saturated aquifer $\left(L^{2}\right)$;

$V_{d}=$ Darcy velocity given by $V_{d}=K \nabla h$, where $K=$ hydraulic conductivity $(\mathrm{L} / \mathrm{t})$ and $\nabla \mathrm{h}=$ itydraulic gradient $(\mathrm{L} / \mathrm{L})$;

$\mathrm{V}_{\mathrm{s}}=$ actual groundwater velocity $\left[\mathrm{V}_{\mathrm{d}} / \phi_{\mathrm{s}}(\mathrm{L} / \mathrm{t})\right]$; and

$\phi_{\mathrm{s}}=$ effective porosity of the saturated zone $\left(\mathrm{L}^{3} / \mathrm{L}^{3}\right)$.

Referring to Figure $4, Q_{h}$ can be written as:

$$
Q_{h}=V_{d} T W
$$

where $\mathrm{T}=$ thickness of the saturated zone. 


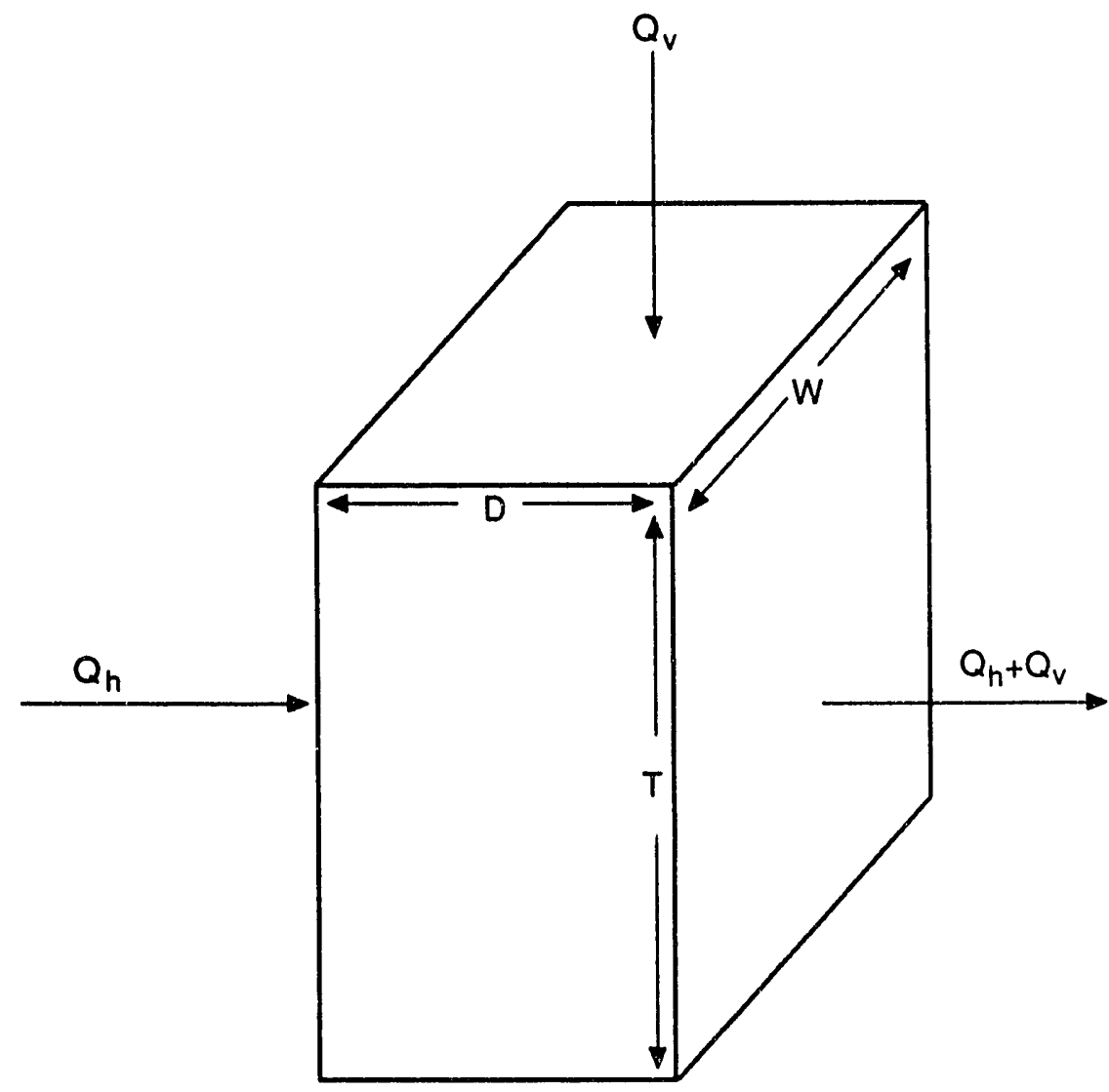

$$
\begin{aligned}
& D=\text { Lateral "depth" extent of contaminated source } \\
& Q_{h}=\text { Horizontal flux } \\
& Q_{v}=\text { Vertical flux } \\
& T=\text { Thickness of saturated zone } \\
& W=\text { Lateral "width" extent of contaminated source }
\end{aligned}
$$

FIGURE 4 Elemental Control Volume for Dilution Model

With the above definitions, Equation 14 can be rewritten as:

$$
D_{1}=\frac{1}{\frac{V_{d}^{T}}{I D \phi_{v}}+1}
$$

In developing Equation 18, infiltrating groundwater outside the area of the disposal cell f ntprint is assumed to have a negligible effect on the flow and thickness of the saturated zone. This assumption provides a conservative estimate of the dilution by limiting the mixing capability of the phreatic zone. 
The dilution factor, $D_{f}$, used in Equation 2 is simply the reciprocal of the dilution:

$$
D_{f}=\frac{1}{D_{1}}
$$

\subsection{PHREATIC TRANSPORT}

Once the contaminant reaches the water table, it is assumed to mix instantaneously and homogeneously with horizontally moving uncontaminated groundwater. After mixing, the contaminant is assumed to be transported laterally to the downgradient receptor. For conservative resuits, transport is once again assumed to be governed by a one-dimensional advection-dispersion equation. The process is represented as:

$$
\frac{\partial C}{\partial t}+\frac{V}{R} \frac{\partial c}{\partial X}=\frac{D}{R} \frac{\partial^{2} C}{\partial X^{2}}
$$

The solution to Equation 20 is the same as that given for vertical transport in the vadose zone, except that the $\mathrm{Z}$ parameter of Equation 13 is set equal to $\mathrm{X}$ to represent transport in the lateral direction and $\Delta t$ is replaced with the full width of the breakthrough curve at the halfmaximum concentration value at the vadose/phreatic zone interface $\left(\Delta t_{1 / 2}\right)$ :

$$
\begin{aligned}
\frac{C}{C_{0}}=\frac{1}{2}\left[\operatorname{ERFC}\left(\frac{X R-V t}{2 \sqrt{D R t}}\right)+e^{\frac{V x}{D}} \operatorname{ERFC}\left(\frac{X R+V t}{2 \sqrt{D R t}}\right)\right] \\
-\frac{1}{2} H\left(t-\Delta t_{1 / 2}\right)\left\{\operatorname{ERFC}\left[\frac{X R-V\left(t-\Delta t_{1 / 2}\right)}{2 \sqrt{D R\left(t-\Delta t_{1 / 2}\right)}}\right]+e^{\frac{V x}{D}} \operatorname{ERFC}\left[\frac{X R+V\left(t-\Delta t_{1 / 2}\right)}{2 \sqrt{D R\left(t-\Delta t_{1 / 2}\right)}}\right]\right\}
\end{aligned}
$$

\subsection{COMPLEX SOLUTION}

In simultaneously solving the coupled vertical and horizontal transport processes, Equation 13 is used as a time-dependent boundary condition for Equation 20 at $X=0$. As a secondary boundary condition, the concentration is assumed to go to zero as the lateral distance, 
$X$, goes to infinity. The vertical coordinate, $Z$, of Equation 13 is therefore set equal to the thickness of the unsaturated zone $\left(Z_{t}\right)$ :

$$
\begin{aligned}
\frac{C\left(X=0, Z=Z_{t} t\right.}{C_{0}}= & \frac{1}{2}\left[\operatorname{ERFC}\left(\frac{Z_{t} R-V t}{2 \sqrt{D R t}}\right)+e^{\frac{V Z_{t}}{D}} \operatorname{ERFC}\left(\frac{Z_{t} R+V t}{2 \sqrt{D R t}}\right)\right] \\
& -\frac{1}{2} H(t-\Delta t)\left\{\operatorname{ERFC}\left[\frac{Z_{t} R-V(t-\Delta t)}{2 \sqrt{D R(t-\Delta t)}}\right]+e^{\frac{V Z_{t}}{D}} \operatorname{ERFC}\left[\frac{Z_{t} R+V(t-\Delta t)}{2 \sqrt{D R(t-\Delta t)}}\right]\right\}
\end{aligned}
$$

The following expression solves Equation 20 in Laplace space subject to the two assumed boundary conditions:

$$
\frac{\bar{C}}{C_{0}}=\frac{1}{S}\left(1-e^{-a s}\right) C_{1} e^{-\sqrt{C_{2}+C_{3} S}} e^{-\sqrt{C_{4}+C_{5} S}}
$$

where:

$$
\begin{aligned}
& a=\Delta t, \\
& C_{1}=e^{\frac{v_{v} Z_{t}}{2 D_{v}} e^{\frac{V_{h} X}{2 D_{h}}},} \\
& C_{2}=\frac{V_{v}^{2} Z^{2}}{4 D_{v}^{2}}, \\
& C_{3}=\frac{Z^{2} R_{v}}{D_{v}}, \\
& C_{4}=\frac{V_{h}^{2} X^{2}}{4 D_{h}^{2}}, \\
& \bar{C}=\text { concentration in Laplace space, and }
\end{aligned}
$$




$$
C_{5}=\frac{X^{2} R_{h}}{D_{h}},
$$

$\mathrm{S}=$ the Laplace variable.

Although the method of convolution can be readily applied to Equation 23 , the resulting integral is not easily evaluated. As an alternative solution, Crump's method (Crump 1976) was used to invert the Laplace transform with the real and imaginary parts of the following Fourier series:

$$
\begin{aligned}
f(t) \simeq & \frac{e^{c t}}{2 T_{m}}\left(\frac { 1 } { 2 } \left\{F(c)+\sum_{K=1}^{\infty}\left[\operatorname{Re} F\left(c+\frac{K \pi i}{2 T_{m}}\right) \cos \left(\frac{K \pi t}{2 T_{m}}\right)\right.\right.\right. \\
& \left.\left.\left.-\operatorname{Im} F\left(c+\frac{K \pi i}{2 T_{m}}\right) \operatorname{SIN}\left(\frac{K \pi t}{2 T_{m}}\right)\right]\right\}\right)
\end{aligned}
$$

where:

$$
\begin{aligned}
c & =\frac{5}{T_{m}}, \\
i & =\sqrt{-1}, \\
\operatorname{Re} & =\text { real part of the complex function, } \\
\operatorname{Im} & =\text { imaginary part of the complex function, and } \\
T_{m} & =\text { maximum time of the calculation. }
\end{aligned}
$$

In implementing Equation 30, the Laplace variable $S$ is replaced with its complex counterpart:

$$
S=c+d i
$$

where:

$$
d=\frac{K \pi}{2 T_{m}}
$$

To solve Equation $30, F(c)$ and $F(S)$ must be formed from Equation 23 , as follows: 


$$
F(c)=\frac{1}{c}\left(1-e^{-a g}\right) C_{1} e^{-\sqrt{C_{2}+C_{3} c}} e^{-\sqrt{C_{4}+C_{5} c}}
$$

and

$$
F(S)=\left(\frac{Z_{1}}{c^{2}+d^{2}}\right) Z_{2} C_{1} e^{-T_{1}} e^{-T_{3}} Z_{3} Z_{4}
$$

where:

$$
\begin{aligned}
& \mathrm{Z}_{1}=\mathrm{c}-\mathrm{di}, \\
& \mathrm{Z}_{2}=\mathrm{P}_{1}+\mathrm{P}_{2} \mathrm{i}, \\
& \mathrm{Z}_{3}=\operatorname{COS}\left(\mathrm{T}_{2}\right)-\mathrm{iSIN}\left(\mathrm{T}_{2}\right), \\
& \mathrm{Z}_{4}=\operatorname{COS}\left(\mathrm{T}_{4}\right)-\mathrm{iSIN}\left(\mathrm{T}_{4}\right), \\
& \mathrm{T}_{1}=\frac{\sqrt{\mathrm{r}_{1}+\sqrt{\mathrm{r}_{1}{ }^{2}+\mathrm{r}_{2}{ }^{2}}}}{\sqrt{2}}, \\
& \mathrm{~T}_{2}=\frac{\sqrt{-\mathrm{r}_{1}+\sqrt{\mathrm{r}_{3}{ }^{2}+\mathrm{r}_{4}{ }^{2}}}}{\sqrt{2}}, \\
& \mathrm{~T}_{3}=\frac{\sqrt{\mathrm{r}_{3}+\sqrt{\mathrm{r}_{3}{ }^{2}+\mathrm{r}_{4}{ }^{2}}}}{\sqrt{2}}, \\
& \mathrm{~T}_{4}=\frac{\sqrt{-\mathrm{r}_{3}+\sqrt{\mathrm{r}_{3}{ }^{2}+\mathrm{r}_{4}{ }^{2}}}}{\sqrt{2}}, \\
& \mathrm{P}_{1}=1-\mathrm{e}^{-\mathrm{ac}} \operatorname{COS}(\mathrm{ad}), \\
& \mathrm{P}_{2}=\mathrm{e}^{-\mathrm{ac}} \mathrm{SIN}(\mathrm{ad}), \\
& \mathrm{r}_{2}=\mathrm{C}_{2}+\mathrm{C}_{3} \mathrm{c},
\end{aligned}
$$




$$
\begin{aligned}
& r_{3}=C_{4}+C_{5} c, \text { and } \\
& r_{4}=C_{5} d
\end{aligned}
$$

In deriving Equation 33, terms of the form

$$
e^{\sqrt{r_{1}+r_{2} i}}
$$

were inconvenient. Such terms were managed, however, by using the following transformation from Wunsch (1983):

$$
e^{\sqrt{X+i Y}}=e^{a+i b}
$$

for

$$
a= \pm \frac{\sqrt{X+\sqrt{X^{2}+Y^{2}}}}{\sqrt{2}}
$$

and

$$
b= \pm \frac{\sqrt{-X+\sqrt{X^{2}}+\overline{Y^{2}}}}{\sqrt{2}}
$$

In addition, the relationship

$$
e^{a+i b}
$$

was conveniently managed by using the following property of the complex exponential function (Wunsch 1983):

$$
e^{a+i b}=e^{a}[\operatorname{COS}(b)+i \operatorname{SIN}(b)]
$$

\footnotetext{
"Note: \pm signs on the radicals must be paired (i.e., either both must be plus or both must be minus). Identical results are obtained for either situation.
} 


\subsection{MODELS}

The mathematical bases for the two transport models are developed in Sections 2.1 and 2.3. The first model simplistically assumes that the contaminant breakthrough curve at the receptor can be obtained by solving the one-dimensional, advection-dispersion equation for an assumed unit step function at the water table. The unit step function has an amplitude equal to the peak water-table concentration and a duration equal to the full width of the breakthrough curve at the half-maximum concentration value. The second model more realistically uses the calculated time-dependent breakthrough curve at the water table as a boundary condition for the horizontal transport calculation. Computer programs were written for each model to compare their predicted results for data from the chemical plant area of the Weldon Spring site located near Weldon Spring, Missouri, and the Envirocare facility located near Clive, Utah.

Because the equations developed for dilution are the same for both models, the effect will be the same: the final concentration at the receptor will be reduced by a constant multiplier (Equation 19) depending on the size of the release and the hydrogeological properties of the vadose and phreatic zones underlying the site. 


\section{Calculations}

To assess the capabilities of the simple, one-dimensional model, calculations were performed with site-specific parameters for the chemical plant area of the Weldon Spring site near Weldon Spring, Missouri, and the Envirocare facility near Clive, Utah. These calculations were then compared with results obtained with the same input parameters but the more complex Fourier series model (Section 2.4).

\subsection{WELDON SPRING SITE}

\subsubsection{Parameters}

In the vicinity of a potential on-site disposal cell at the chemical plant area, the vadose zone has an approximate thickness of $15 \mathrm{~m}$ (50 ft) (DOE 1992b). The overburden at the site consists of five layers: topsoil and loess, Ferrelview clay, clay till, basal till, and residuum. An effective overburden model that was developed from laboratory measurements by Bognar (1991) indicates that the harmonic mean saturated hydraulic conductivity of the overburden is about $3.09 \times 10^{-8} \mathrm{~cm} / \mathrm{s}\left(8.8 \times 10^{-5} \mathrm{ft} / \mathrm{d}\right)$ for a thickness of $6 \mathrm{~m}(20 \mathrm{ft})$. For this study, the thickness of the overburden was assumed to be $9.1 \mathrm{~m}(30 \mathrm{ft})$, and the saturated hydraulic conductivity was assumed to be $1.0 \times 10^{-7} \mathrm{~cm} / \mathrm{s}\left(2.8 \times 10^{-4} \mathrm{ft} / \mathrm{d}\right)$. These values were chosen to be consistent with Missouri state law for landfills, which requires a minimum thickness for the overburden of $9.1 \mathrm{~m}$ $(30 \mathrm{ft})$ and a maximum conductivity of $1.0 \times 10^{-7} \mathrm{~cm} / \mathrm{s}\left(2.8 \times 10^{-4} \mathrm{ft} / \mathrm{d}\right)$. For conservative results, transport through the composite overburden material was assumed to occur under saturated conditions, with an infiltration velocity equal to the harmonic mean of the hydraulic conductivity. Dispersivity was assumed to be scale dependent (Lallemand-Barrès and

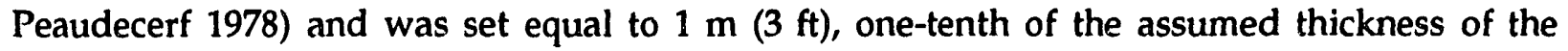
overburden.

\subsubsection{Results}

The results of dimensionless contaminant concentration calculations for the simplified model obtained with Equation 13 for the unsaturated zone are shown in Figures 5 and 6 and are summarized in Table 1 for retardation values of 1,5 , and 100, respectively. The value of 1 represents a purely conservative solute such as nitrate (i.e., no retardation). The value of 5 represents contaminants that can be relatively mobile in porous media (e.g., lithium and arsenic). The retardation factor of 100 represents relatively immobile species such as antimony, nickel, and thallium (Sheppard et al. 1984; Baes and Sharp 1983; Baes et al. 1984).

For all calculations involving the Weldon Spring site, the disposal cell was assumed to discharge its entire liquid contents to the underlying overburden in 150 years. This number is based on a disposal cell having an assumed height of $23 \mathrm{~m} \mathrm{(75} \mathrm{ft),} \mathrm{an} \mathrm{assumed} \mathrm{effective} \mathrm{porosity}$ of 0.2 , and an infiltration velocity of $1.0 \times 10^{-7} \mathrm{~cm} / \mathrm{s}\left(2.8 \times 10^{-4} \mathrm{ft} / \mathrm{d}\right)$. 

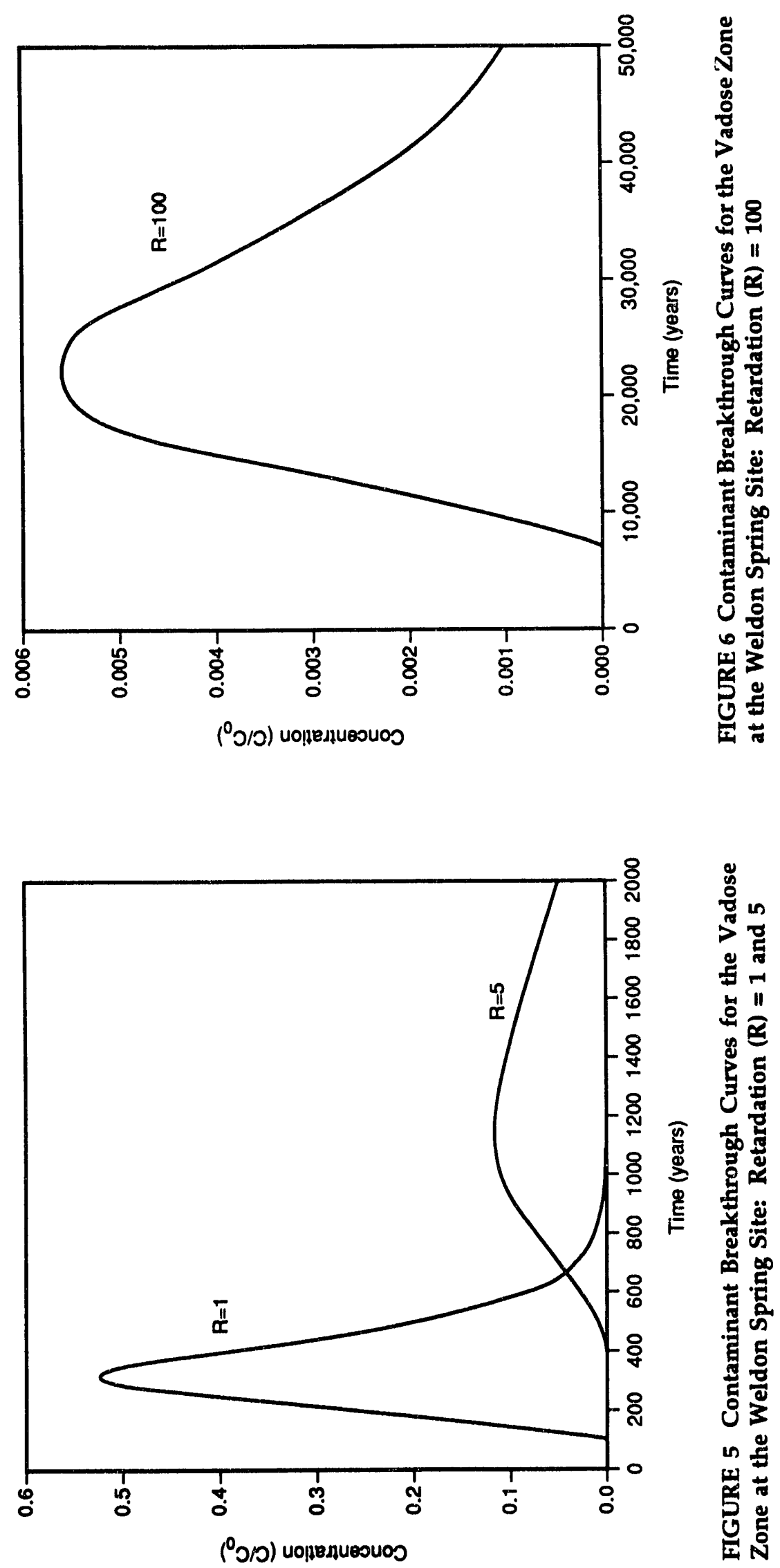
TABLE 1 Summary of Disposal Cell Failure Calculations for the Weldon Spring Site: One-Dimensional Vadose Zone ${ }^{\mathrm{a}}$

\begin{tabular}{ccccc}
\hline Retardation & $\begin{array}{c}\text { Maximum } \\
\text { Concentration } \\
\text { at Bottom of } \\
\text { Unsaturated Zone } \\
\text { (percent of initial } \\
\text { concentration) }\end{array}$ & $\begin{array}{c}\text { Time of } \\
\text { Maximum } \\
\text { Concentration } \\
\text { at Bottom of } \\
\text { Unsaturated Zone } \\
\text { (years) }\end{array}$ & $\begin{array}{c}\text { Duration at } \\
\text { Half-Maximum } \\
\text { (years) }\end{array}$ & $\begin{array}{c}\text { Time Shift } \\
\text { to First } \\
\text { Half-Maximum } \\
\text { (years) }\end{array}$ \\
\hline 1 & 52 & 300 & 250 & 200 \\
5 & 12 & 1,160 & 1,160 & 730 \\
100 & 0.6 & 22,000 & 23,500 & 13,000 \\
\hline
\end{tabular}

a These calculations include only the vertical flow component through the vadose (unsaturated) zone.

After the contaminated water in the unsaturated zone reached the water table, mixing would occur with groundwater assumed to be initially uncontaminated (see discussion in Chapter 2). Mixing was assumed to occur instantaneously and homogeneously throughout the thickness of the saturated zone. The effects of dilution for the Weldon Spring site were assessed with Equation 19. Site-specific parameters for this assessment included an arbitrary disposal cell failure length parallel to the direction of groundwater flow of $60 \mathrm{~m}(200 \mathrm{ft})$, an unsaturated zone effective porosity of 0.3 , a saturated thickness of $8 \mathrm{~m}(25 \mathrm{ft})$, a saturated zone e rective porosity of 0.2 , a hydraulic gradient in the vicinity of the chemical plant area of 0.02 , and a hydraulic conductivity value of $0.0044 \mathrm{~cm} / \mathrm{s}(12.5 \mathrm{ft} / \mathrm{d}$ ) (Bechtel National 1987). For these parameters, the dilution factor is about 380 . This value of dilution also applies to the second model that solves the coupled transport problem with a more complex time-dependent boundary condition at the vadose/phreatic zone interface.

Once the contaminants were mixed with groundwater in the saturated zone, transport to the receptor was assumed to follow natural flow lines; flow is predominantly horizontal and to the north (DOE 1992a, 1992b). For the Weldon Spring site trie distance from the disposal cell to the site boundary was assumed to be about $300 \mathrm{~m}(1,0,00 \mathrm{ft})$. From the disposal cell to the receptor, the unconfined aquifer was assumed to be laterally homogeneous with a hydraulic gradient of about 0.02 , an effective porosity of 0.2 (Freeze and Cherry 1979), and a hydraulic conductivity of $0.0044 \mathrm{~cm} / \mathrm{s}(12.5 \mathrm{ft} / \mathrm{d})$. For these conditions, the average linear groundwater velocity (Darcy velocity divided by effective porosity) in the phreatic zone is about $0.38 \mathrm{~m} / \mathrm{d}$ $(1.25 \mathrm{ft} / \mathrm{d})$.

As with the overburden transport calculations, a scale-dependent dispersivity was assumed for the upper, weathered portion of the Burlington-Keokuk Limestone aquifer (Lallemand-Barrès and Peaudecerf 1978) where contaminant transport is most likely to occur 
(DOE 1992a). For a 300-m (1,000-ft) separation distance, the dispersivity was assumed to be $30 \mathrm{~m}(100 \mathrm{ft})$.

For transport calculations through the vadose zone, the source was assumed to have a duration of 150 years. As indicated in Figures 5 and 6, the duration of the contaminant pulse increases at the interface of the unsaturated and saturated zones whereas the peak concentration decreases because of dispersion. A step-function source having a duration equal to the full width of the breakthrough curve at the half-maximum concentration was used to estimate the lateral transport. From Figures 5 and 6, the full widths of the contaminant pulses at the interface at the half-maximum concentration values are 260,1,160, and 23,500 years for retardation values of 1,5 , and 100 , respectively (Table 1 ). In addition, the shift times for the step-function source at the water table are 200,730 , and 13,000 years for retardations of 1, 5, and 100, respectively (Table 1). The half-maximum duration times were then employed in the solution to Equation 20 to evaluate transport in the horizontal direction; the shift times were used to evaluate the overall effect at the receptor.

Figures 7 and 8 illustrate the results obtained for a receptor located at a downgradient

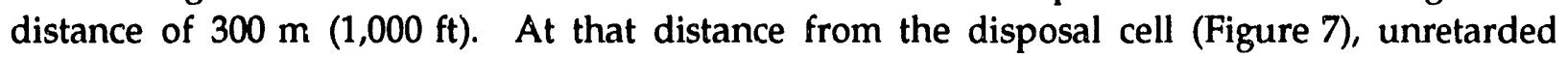
contaminants would reach a maximum concentration of $100 \%$ of their initial value (peak value of the unsaturated breakthrough curve at the interface of the vadose and phreatic zones divided by the dilution factor) in about 12 years. Moderately and highly retarded contaminants would also reach $100 \%$ concentration after about 58 and 540 years, respectively.

Combining the results obtained from Equations 1 and 2 for the three separate calculations (overburden, dilution, and saturated lateral flow) yields the following conservative results for the entire flow system (i.e., from the top of the overburden to a potential receptor $300 \mathrm{~m}$ $[1,000 \mathrm{ft}]$ downgradient of the source). For conservative solutes (retardation value of 1 ), the time required to achieve a maximum solute concentration $(0.14 \%$ of the initial leachate value) is approximately 212,236 , and 252 years for the three receptor locations. For moderately retarded solutes (retardation value of 5 ), the time required to achieve a maximum concentration $(0.032 \%$ of the initial leachate value) is approximately 788,902 , and 978 years. For relatively immobile solutes (retardation value of 100 ), the time required to achieve a maximum concentration $(0.0016 \%$ of the initial leachate value) is approximately $13,540,16,400$, and 17,950 years.

To evaluate the effect of the simplifying assumptions made in the first model, the same calculations were repeated with the more complex conceptual model defined by Equation 30 . For consistency, the same parameters that defined the transport process for the simple model were used in the second set of calculations.

Comparisons between the two models without the effects of dilution (same constant multiplier for both models) for retardation values of 1 and 100 are shown in Figures 9 and 10, respectively. The results indicate that the simple model correctly predicts the peak concentration at the location of the receptor. Because transport through the phreatic zone is rapid, the contaminant concentration at the receptor achieves a value of $100 \%$ of the concentration at the 

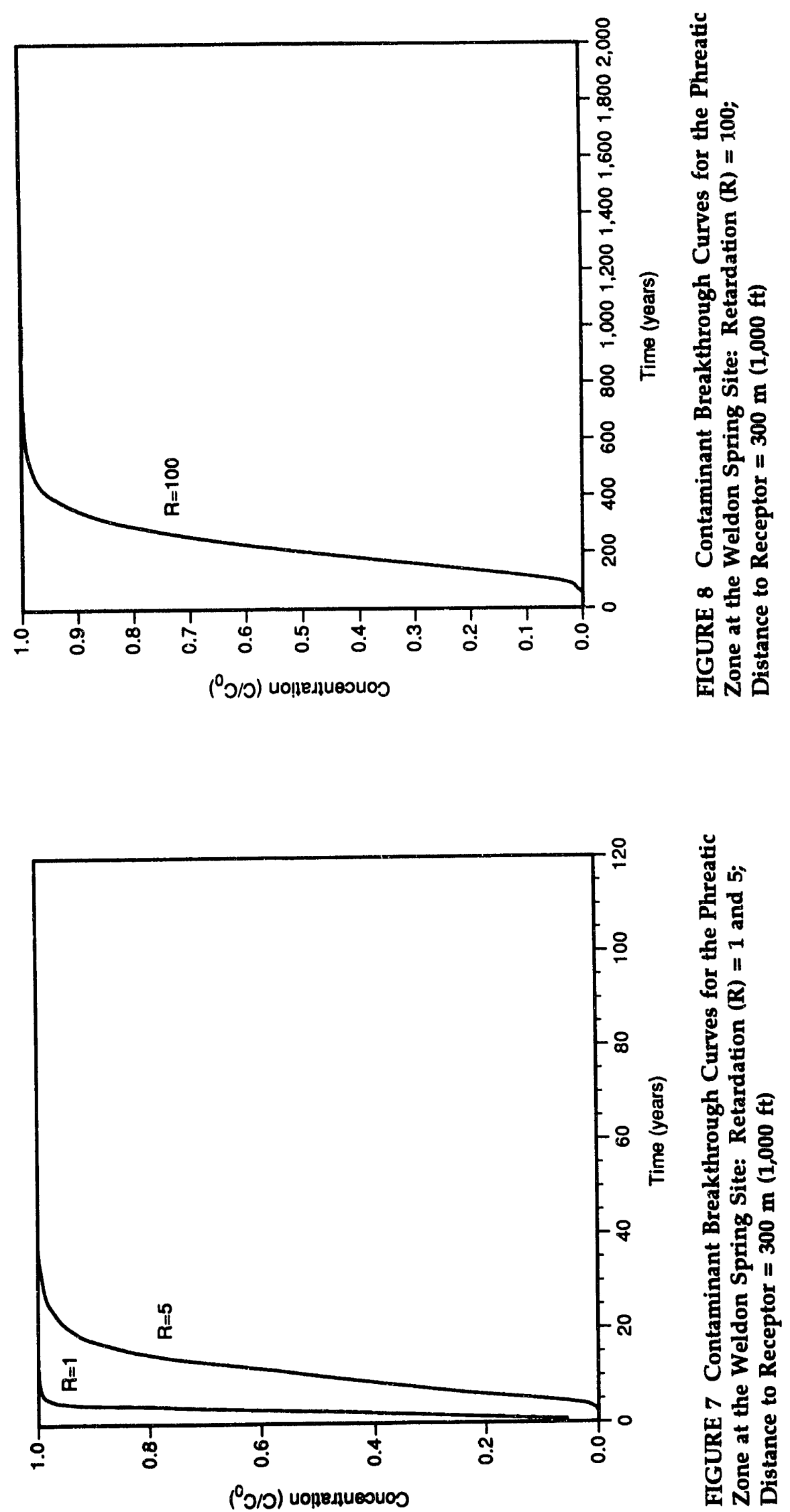

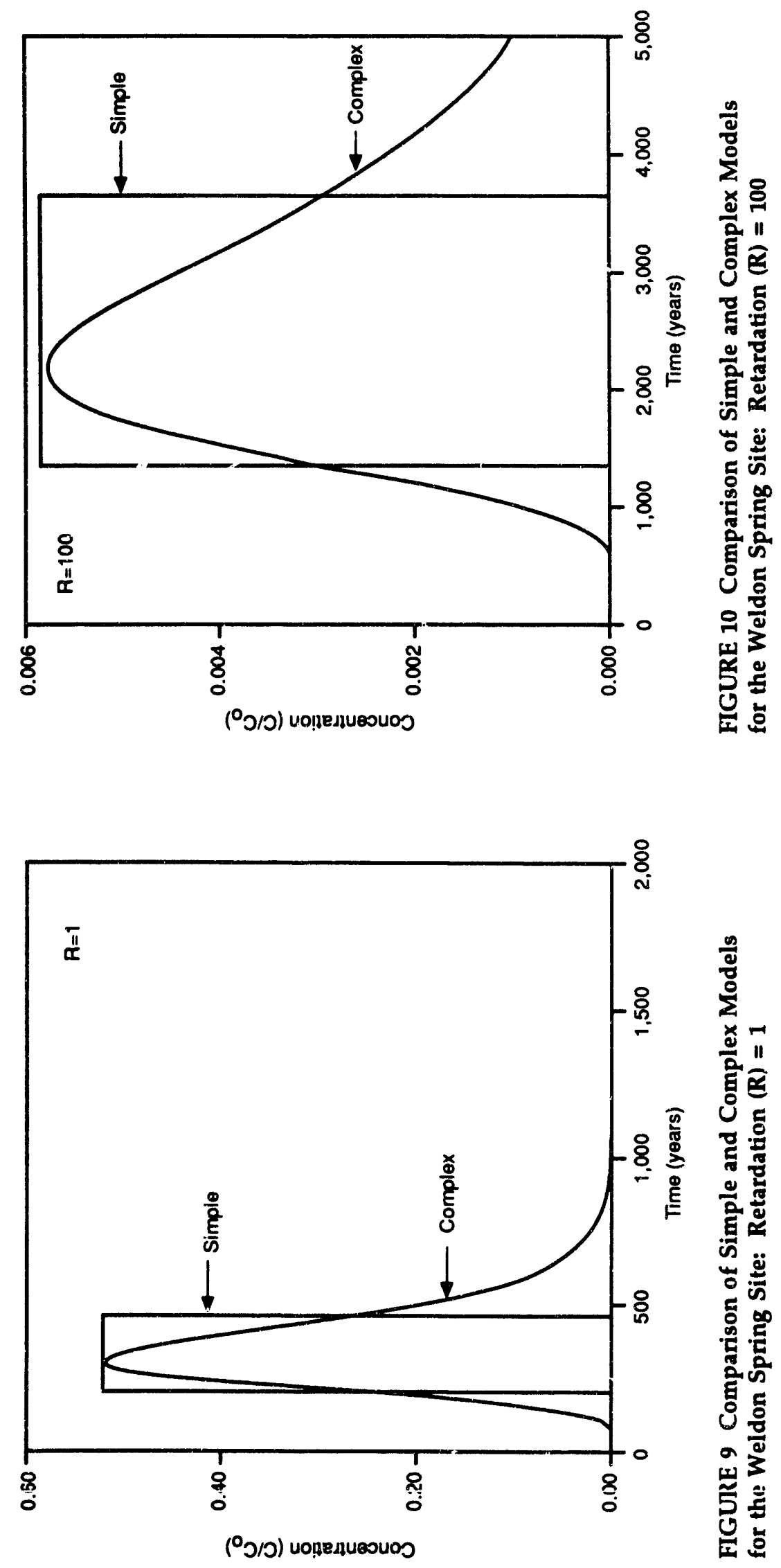
vadose/phreatic zone interface directly below the disposal cell. This effect produces a squarewave response at the receptor. Initial breakthroughs at the receptor, therefore, occur later than those predicted by the second model whereas the peak contaminant concentration is reached earlier. Because of the assumed square-wave shape of the source at the water table below the disposal cell and the $100 \%$ breakthrough concentration of the contaminant at the receptor, peak breakthroughs at the receptor can conservatively occur before peak concentration at the vadose/ phreatic zone interface. In addition, both models yield the same total mass in the contaminant plume and time for the half-maximum value. The simple model is thus seen to produce a conservative estimate of the breakthrough curve (peak concentration and time to the peak concentration) at the downgradient receptor.

\subsection{ENVIROCARE FACILITY}

\subsubsection{Parameters}

In the vicinity of a potential disposal cell at the Envirocare facility near Clive, Utah, the

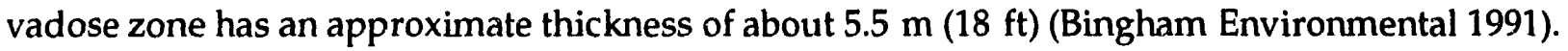

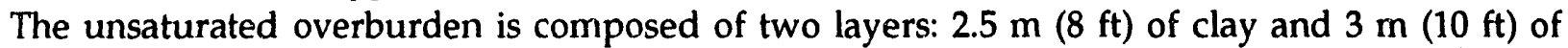
silty sand. The clay has an average saturated hydraulic conductivity of about $1.9 \times 10^{-7} \mathrm{~cm} / \mathrm{s}$ $\left(5.4 \times 10^{-4} \mathrm{ft} / \mathrm{d}\right)$, whereas the silty sand has a conductivity of about $5.6 \times 10^{-5} \mathrm{~cm} / \mathrm{s}(0.16 \mathrm{ft} / \mathrm{d})$. An equivalent composite overburden was assumed for the vadose zone calculations. This

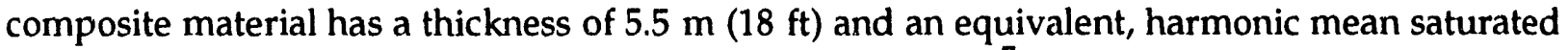
hydraulic conductivity (Freeze and Cherry 1979) of $4.3 \times 10^{-7} \mathrm{~cm} / \mathrm{s}(0.0012 \mathrm{ft} / \mathrm{d}$ ).

Infiltration of the leachate from the disposal cell was assumed to begin with the waste material fully saturated. Infiltration was assumed to occur with an average linear groundwater velocity equal to the harmonic mean of the saturated hydraulic conductivity of the composite overburden. The rate of contaminant infiltration below an equivalent disposal cell at the Envirocare facility would be approximately 4.3 times faster than that the Weldon Spring site because of the higher saturated hydraulic conductivity material beneath the Envirocare site. A disposal cell at this site would empty its leachate contents in about 35 years following cell failure. Dispersivity was assumed to be scale dependent (Lallemand-Barrès and Peaudecerf 1978 ) and was set equal to $0.5 \mathrm{~m}(1.8 \mathrm{ft})$, one-tenth of the average thickness of the composite material.

\subsubsection{Results}

The results of dimensionless contaminant concentration calculations obtained with Equation 13 for the unsaturated zone at the Envirocare facility are shown in Figures 11 and 12 and summarized in Table 2 for retardations values of 1,5, and 100, respectively. 


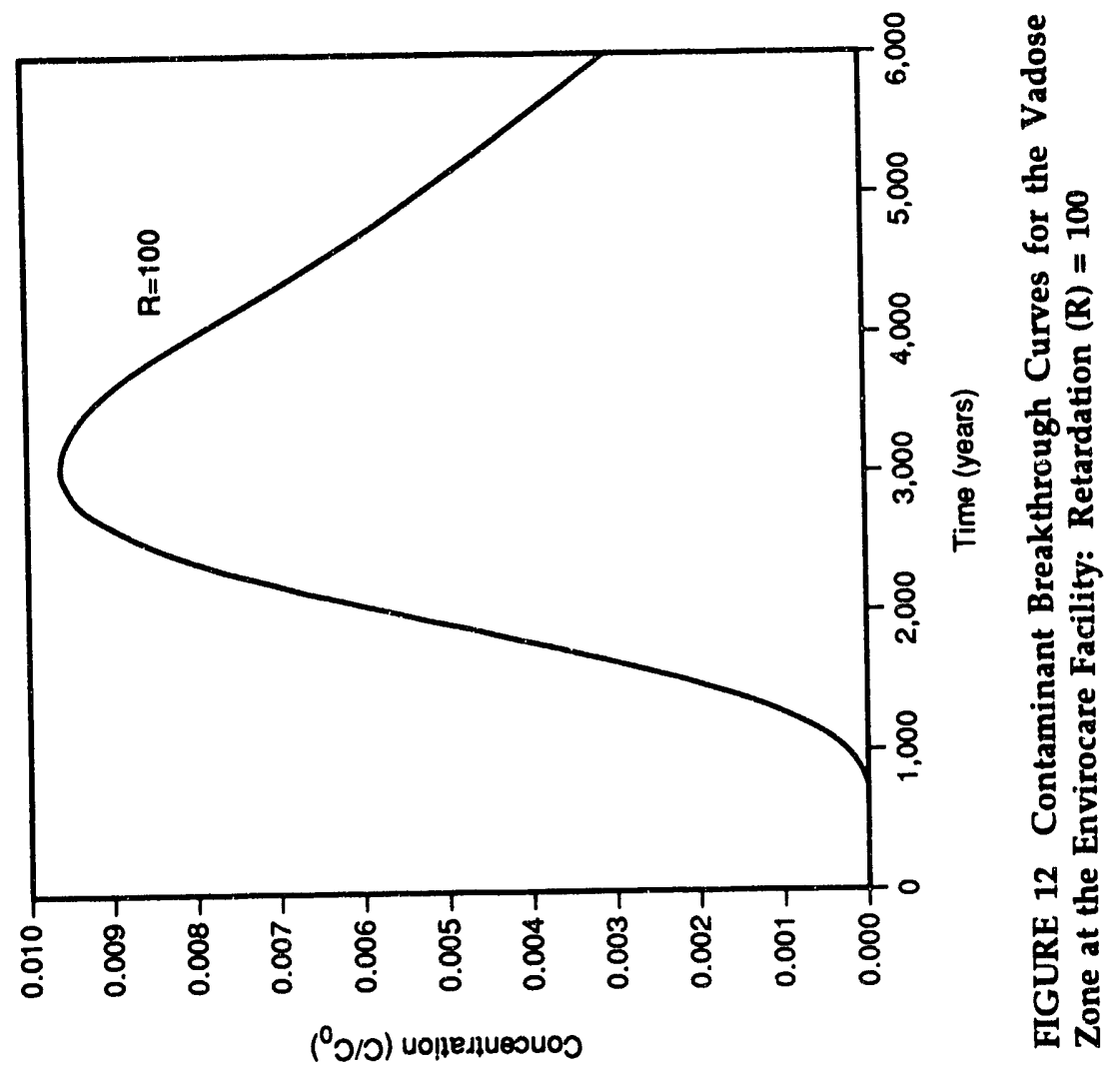

1

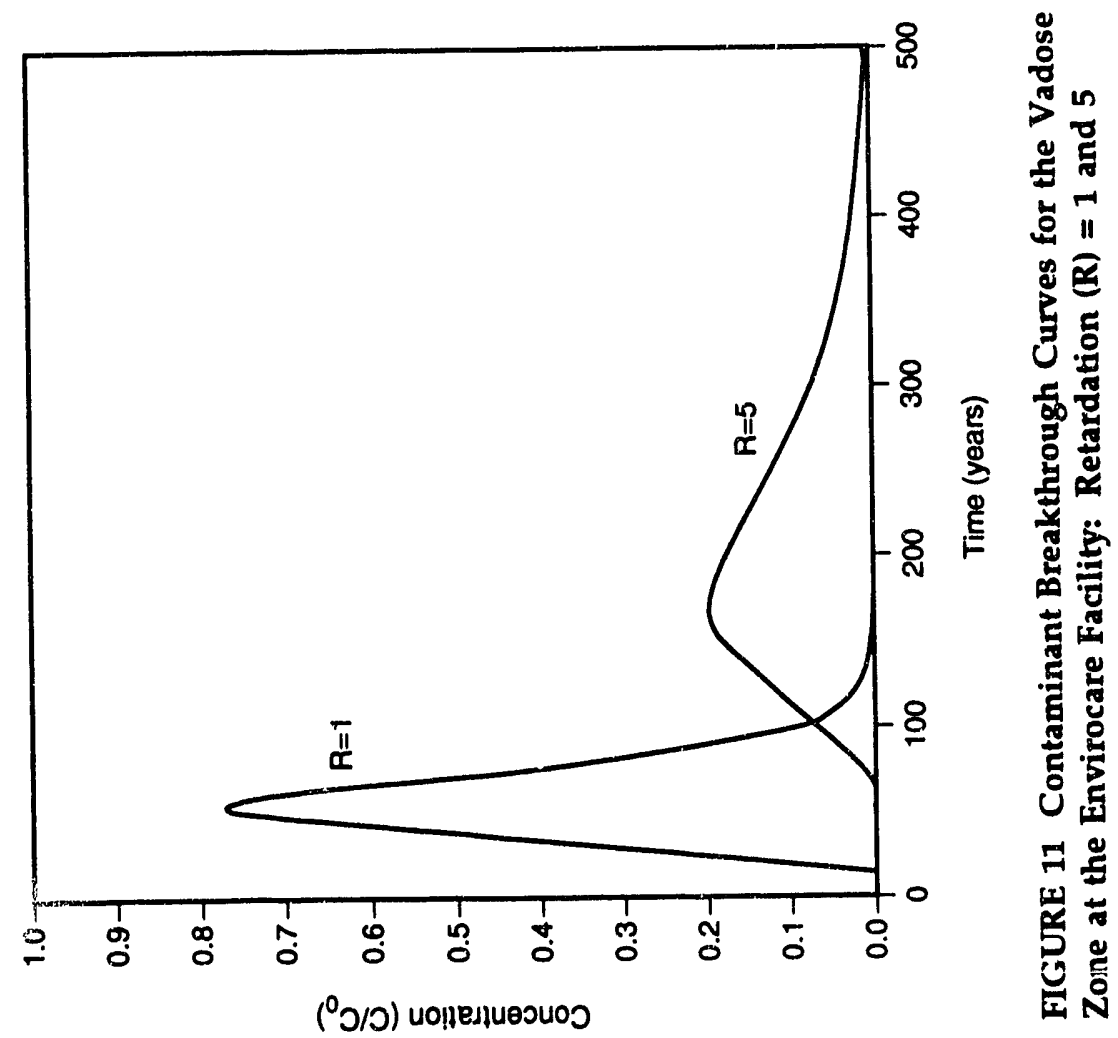


TABLE 2 Summary of Disposal Cell Failure Calculations for the Envirocare Facility: One-Dimensional Vadose Zone

\begin{tabular}{ccccc}
\hline & $\begin{array}{c}\text { Maximum } \\
\text { Concentration } \\
\text { at Bottom of } \\
\text { Unsaturated Zone } \\
\text { (percent of initial } \\
\text { concentration) }\end{array}$ & $\begin{array}{c}\text { Time of } \\
\text { Maximum } \\
\text { Concentration } \\
\text { at Bottom of } \\
\text { Unsaturated Zone } \\
\text { (years) }\end{array}$ & $\begin{array}{c}\text { Duration at } \\
\text { Half-Maximum } \\
\text { (years) }\end{array}$ & $\begin{array}{c}\text { Time Shift } \\
\text { to First } \\
\text { Half-Maximum } \\
\text { (years) }\end{array}$ \\
\hline 1 & 75 & 55 & 42 & 32 \\
5 & 19 & 170 & 160 & 110 \\
100 & 1 & 3,050 & 3,300 & 1,860 \\
\hline
\end{tabular}

a These calculations include only the vertical flow component through the vadose (unsaturated) zone.

After the contaminated water in the unsaturated zone reached the water table, mixing would occur with groundwater assumed to be initially clean. Mixing was assumed to occur instantaneously and homogeneously throughout the thickness of the saturated zone. The effects of dilution for the Envirocare facility were assessed with Equation 19. Site-specific parameters for this assessment included a disposal cell length parallel to the direction of groundwater flow of about $60 \mathrm{~m}(200 \mathrm{ft})$, an unsaturated zone effective porosity of 0.3 , a saturated thickness of

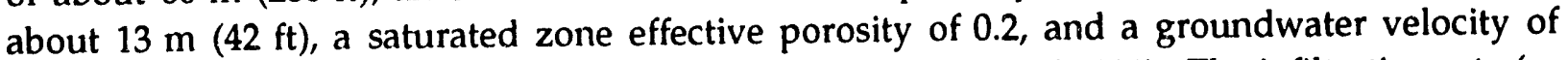
$7 \mathrm{~m} / \mathrm{yr}(23 \mathrm{ft} / \mathrm{yr}$ ) in the saturated zone (Bingham Environmental 1991). The infiltration rate (as discussed in Section 2.1) was assumed to be equal to the harmonic mean of the saturated hydraulic conductivity of the composite overburden $\left(4.3 \times 10^{-7} \mathrm{~cm} / \mathrm{s}[5 \mathrm{in} . / \mathrm{yr}]\right)$. At this rate of infiltration, the dilution factor is about 8.2. This is the same value that would be used in the Fourier series transport model.

After mixing with groundwater in the saturated zone, migration to the receptor would follow natural flow lines; flow is predominantly horizontal and to the north. One receptor location was considered for the Envirocare facility. This receptor was assumed to be located on the site boundary about $1,600 \mathrm{~m}(5,280 \mathrm{ft})$ from the disposal cell.

The average linear groundwater velocity (Darcy velocity divided by effective porosity) in the unconfined uppermost groundwater aquifer at the Envirocare facility is about $0.019 \mathrm{~m} / \mathrm{d}$ $(0.062 \mathrm{ft} / \mathrm{d})$. A scale-dependent dispersivity was assumed for the lateral transport calculations

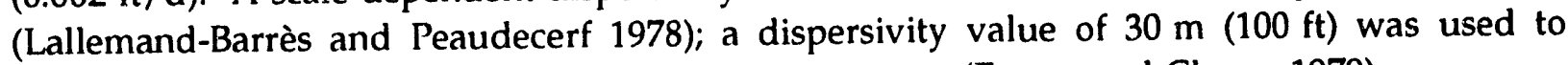
produce conservative breakthrough concentration curves (Freeze and Cherry 1979).

For the unsaturated transport calculations at the Envirocare facility, a source having a duration of about 35 years was assumed. As indicated in Figures 11 and 12, the source duration increases at the interface of the unsaturated and saturated zones, whereas the peak concentration 
decreases because of dispersion. As for the Weldon Spring site, a step-function source having a duration equal to the full width of the breakthrough curve at the half-maximum concentration value was used to estimate lateral transport. The full widths of the contaminant pulses at the interface at the half-maximum concentration values are 42,160 , and 3,300 years for retardation values of 1,5, and 100, respectively (Figures 11 and 12). In addition, the shift times for the stepfunction source at the water table are 32, 110, and 1,860 years for retardations of 1, 5, and 100, respectively (Table 2 ). The half-maximum duration times were then employed in solving Equation 20 to evaluate transport in the horizontal direction; the shift times were used to evaluate the overall effect at the receptor.

Figures 13 and 14 illustrate the results obtained for a receptor located 1,600 m (5,280 ft) from the disposal cell. Unretarded contaminants achieve a maximum concentration of about $38 \%$ of their initial value (unsaturated peak breakthrough concentration at the interface between the vadose and phreatic zones divided by the dilution factor) in about 240 years (Figure 14). Moderately retarded contaminants achieve a maximum concentration of about $29 \%$ after about 1,160 years (Figure 14). Contaminants with a retardation value of 100 achieve a peak concentration of about $30 \%$ in about 23,500 years.

Combining the results of the three separate calculations (overburden, dilution, and saturated lateral flow) yields the following conservative results for the entire flow system (i.e., from the top of the overburden to the potential receptor $1,600 \mathrm{~m}[5,280 \mathrm{ft}]$ downgradient of the disposal cell). For conservative solutes, the time required to achieve a maximum contaminant concentration (3.3\% of the initial leachate value) is about 272 years. For moderately retarded contaminants, the time required to achieve a maximum concentration $(0.62 \%$ of the initial leachate value) is about 1,270 years. For relatively immobile solutes, the time required to achieve a maximum concentration ( $0.033 \%$ of the initial leachate value) is about 25,360 years.

Figures 15 and 16 illustrate comparisons between the two models without the effects of dilution (same constant multiplier for both models) for retardation values of 1 and 5 , respectively. The comparisons indicate that the simple model nearly replicates the results of the more complex Fourier series model. Both models show that the shape of the breakthrough curve at the receptor becomes less dependent on the time-dependent shape of the source as the distance between a receptor and a source increases or as the groundwater seepage velocity decreases. This result differs from the case at the Weldon Spring site in which the simple model results at the receptor replicated the square-wave source at the vadose/phreatic zone interface. This difference occurs because of the difference in properties between the two phreatic zones and the much longer transport distance at the Envirocare facility, where the peak concentration at the receptor for the simple model does not reach $100 \%$ of its value at the interface. For the Envirocare facility, the simple model again produces a conservative estimate of the breakthrough curve (peak concentration and time to the peak concentration) at the downgradient receptor. 

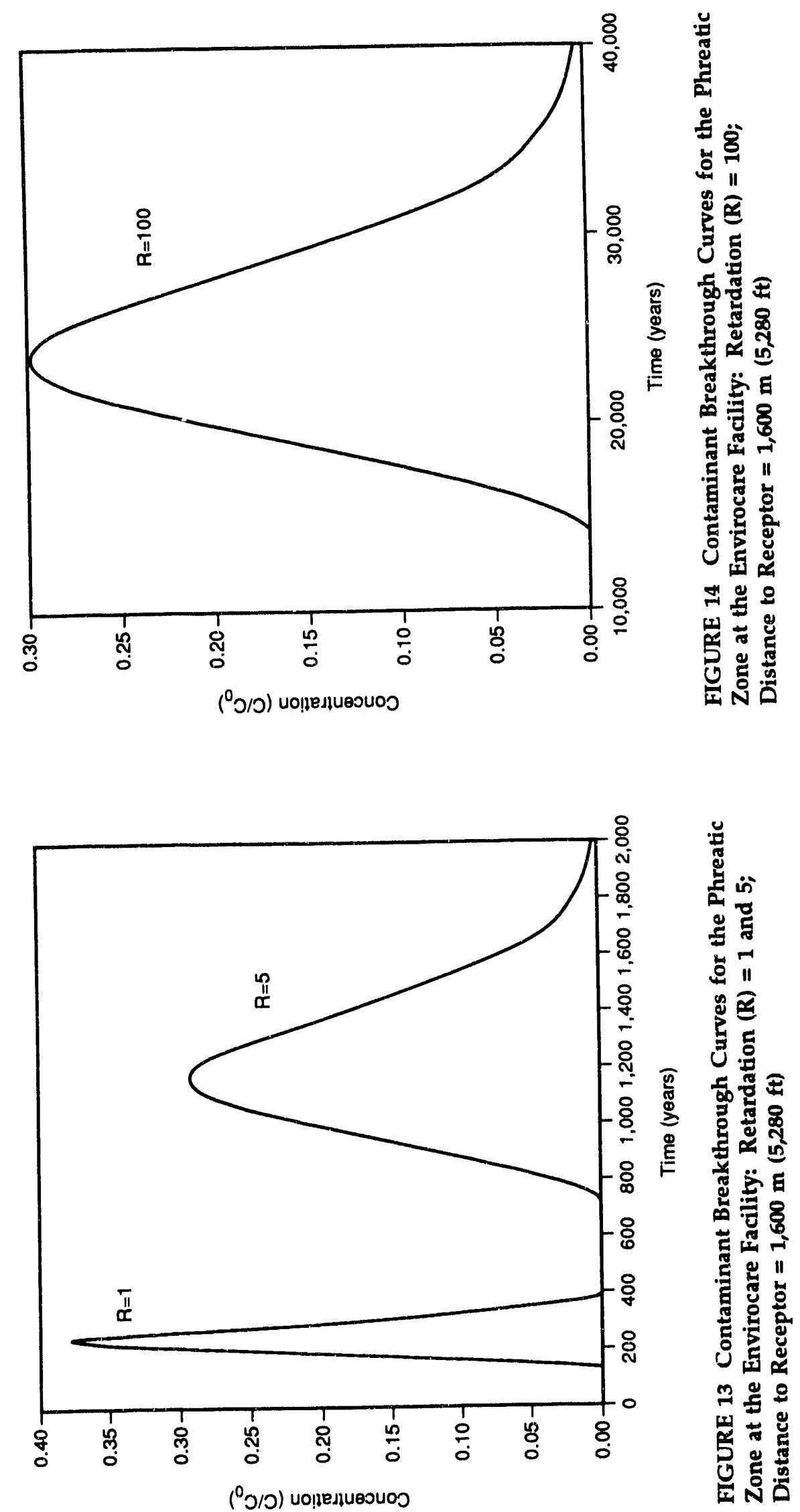

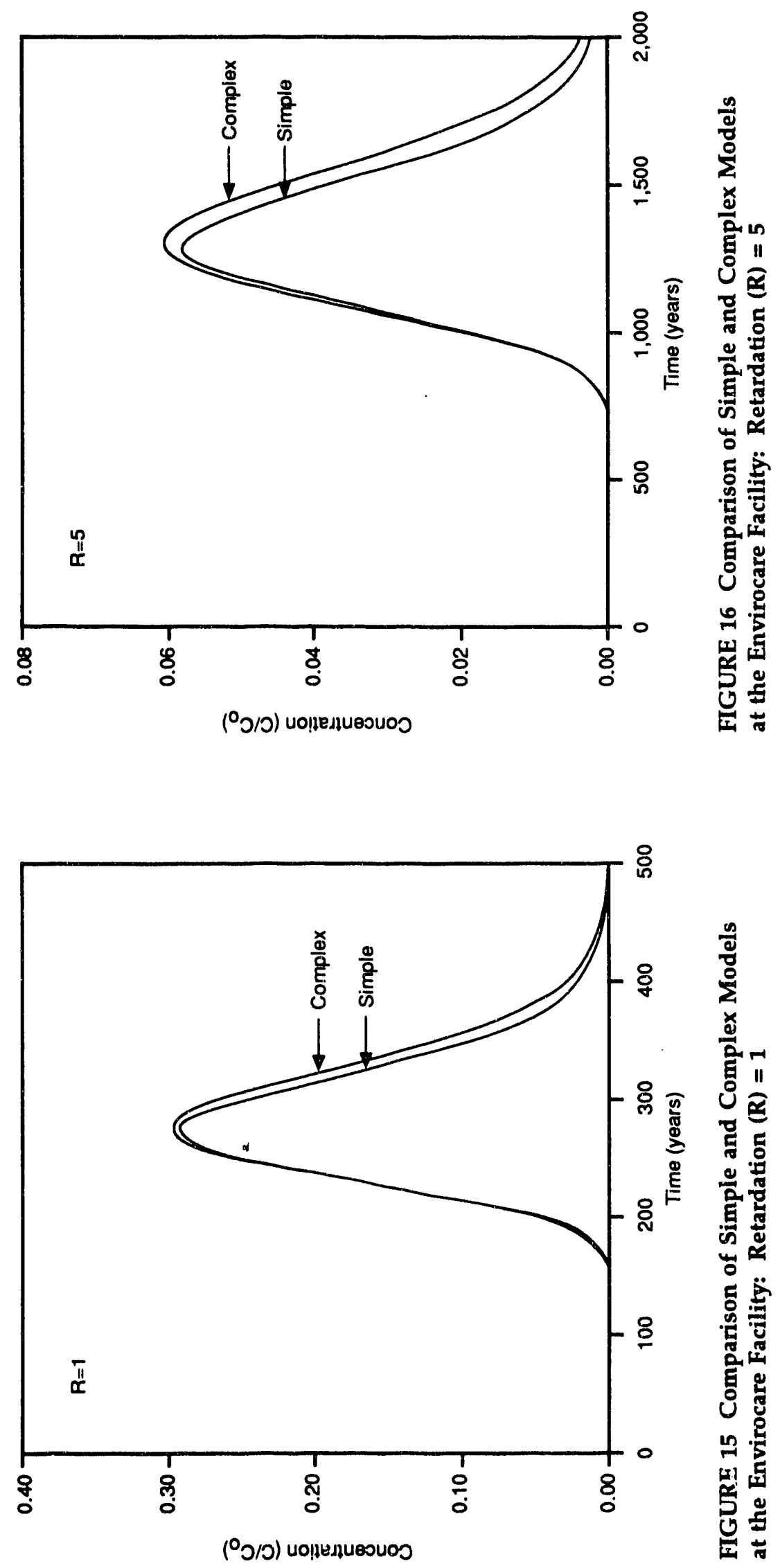


\section{CONCLUSIONS}

Two models - one simple and the other complex - were developed to evaluate the concentration of a contaminant released from a disposal cell at a downgradient receptor location after vertical transport through an unsaturated zone, mixing at the vadose/phreatic zone interface, and lateral transport through an unconfined aquifer. The simple model used a unitsquare wave source at the interface of the vadose and phreatic zones to approximate the shape of the time-dependent contaminant breakthrough curve. Evaluating the breakthrough curve only requires relatively simple computation of exponential and complementary error functions. A precise numerical evaluation of the coupled partial differential equations required a sophisticated mathematical methodology to invert the Laplace space solution.

The models were used to evaluate a hypothetical disposal cell failure on the basis of site-specific parameters for the chemical plant area of the Weldon Spring site near Weldon Spring, Missouri, and the Envirocare facility near Clive, Utah. The results indicated that the simple model produced conservative estimates of both the peak concentration of the contaminant at the receptor location and the time to achieve this peak value. In addition, the simple model preserved the time to reach a half-maximum contaminant concentration and conserved mass. For the case in which the receptor is located at a significant distance from the interface of the vadose/phreatic zone interface and the hydraulic properties of the saturated aquifer result in small seepage velocities, the simple model nearly replicates the results of the Fourier series methodology.

Because the simple model produces conservative results for a complex process and can be easily implemented on a personal computer or solved with tabular lookups, it is recommended for quick, scoping calculations. If higher accuracy is desired or required, the more complex model should be used. 


\section{REFERENCES}

Baes, C.F., and R.D. Sharp, 1983, A Proposal for Estimation of Soil Leaching and Leaching Constants for Use in Assessment Models, Journal of Environmental Quality, 12(1):17-28.

Baes, C.F., et al., 1984, A Review and Analysis of Parameters for Assessing Transport of Environmentally Released Radionuclides through Agriculture, ORNL-5786, prepared by Oak Ridge National Laboratory, Oak Ridge, Tenn., for U.S. Department of Energy, Oak Ridge Operations, Oak Ridge, Tenn.

Bear, J., 1972, Dynamics of Fluids in Porous Media, American Elsevier Publishing Company, New York.

Bechtel National, Inc., 1987, Hydrogeological Characterization Report for the Weldon Spring Chemical Plant, DOE/OR/20722-137, prepared for U.S. Department of Energy, Oak Ridge Operations Office, Oak Ridge, Tenn.

Bingham Environmental, 1991, Hydrogeologic Report, Envirocare Waste Disposal Facility, South Clive, Utah, prepared for Envirocare of Utah, Salt Lake City, May.

Bognar, J.L., 1991, Permeability of the Multilayer Overburden System at the Weldon Spring Site, in Proceedings of the Geosciences Workshop, DOE/OR/21548-197, published by MK-Ferguson Company and Jacobs Engineering Group for U.S. Department of Energy, Oak Ridge Operations Office, Weldon Spring Remedial Action Project, St. Charles, Mo., March, pp. 245 ^.75.

Crump, K.S., 1976, Numerical Inversion of Laplace Transforms Using a Fourier Series Approximation, Journal of the Association for Computing Machinery, 23(1):89-96.

Ditkin, V.A., and A.P. Prudnikov, 1967, Formulaire pour le Calcul Operationnel, Masson et Cie, Editeurs, Paris.

Freeze, R.A., and J.A. Cherry, 1979, Groundwater, Prentice-Hall, Inc., Englewood Cliffs, N.J.

Hildebrand, F.B., 1976, Advanced Calculus for Applications, Prentice-Hall, Inc., Englewood Cliffs, N.J.

Kreyszig, E., 1967, Advanced Engineering Mathematics, John Wiley and Sons, Inc., New York.

Lallemand-Barrès, A., and P. Peaudecerf, 1978, Recherche des Relations entre a Valeur de la Dispersivité Macroscopique d'un Milieu Aquifere, Ses Autres Caractéristiques et les Conditions de Mesure, Bulletin Bureau Geologique Minières, 4-1978:277-284. 
Sheppard, M.l., et al., 1984, Soil Nuclide Distribution Coefficients and Their Statistical Distributions, AECL-8384, Whiteshell Nuclear Research Establishment, Atomic Energy of Canada Limited, Pinawa, Manitoba.

Tomasko, D., 1989, The Effects of a Perturbed Source on Contaminant Transport Near the Weldon Spring Quarry, ANL/EES-TM-370, prepared for U.S. Department of Energy, Oak Ridge Operations Office, Weldon Spring Site Remedial Action Project, St. Charles, Mo., March.

Tomasko, D., 1990, The Effect of a Zero-Concentration Sink on Contaminant Transport and RemedialAction Designs for the Weldon Spring Quarry, Weldon Spring, Missouri, ANL/EAIS/TM-31, prepared for U.S. Department of Energy, Oak Ridge Operation Office, Weldon Spring Site Remedial Action Project, St. Charles, Mo., April.

U.S. Department of Energy, 1992a, Baseline Assessment for the Chemical Plant Area of the Weldon Spring Site, DOE/OR/21548-091, prepared by Argonne National Laboratory, Environmental Assessment and Information Sciences Division, Argonne, Ill., for U.S. Department of Energy, Oak Ridge Field Office, Weldon Spring Site Remedial Action Project, St. Charles, Mo., Nov.

U.S. Department of Energy, 1992b, Remedial Investigation for the Chemical Plant Area of the Weldon Spring Site, DOE/OR/21548-074, Rev. 0, Vols. I-II, prepared by MK-Ferguson Company and Jacobs Engineering Group, Weldon Spring, Mo., for U.S. Department of Energy, Oak Ridge Field Office, Weldon Spring Site Remedial Action Project, St. Charles, Mo., Nov.

U.S. Environmental Protection Agency, 1989, Determining Soil Response Action Levels Based on Potential Contaminant Migration to Ground Water: A Compendium of Examples, EPA/540/2-89/057, Office of Emergency and Remedial Response, Washington, D.C.

Wunsch, A.D., 1983, Complex Variables with Applications, Addison-Wesley Publishing Company, Reading, Mass. 

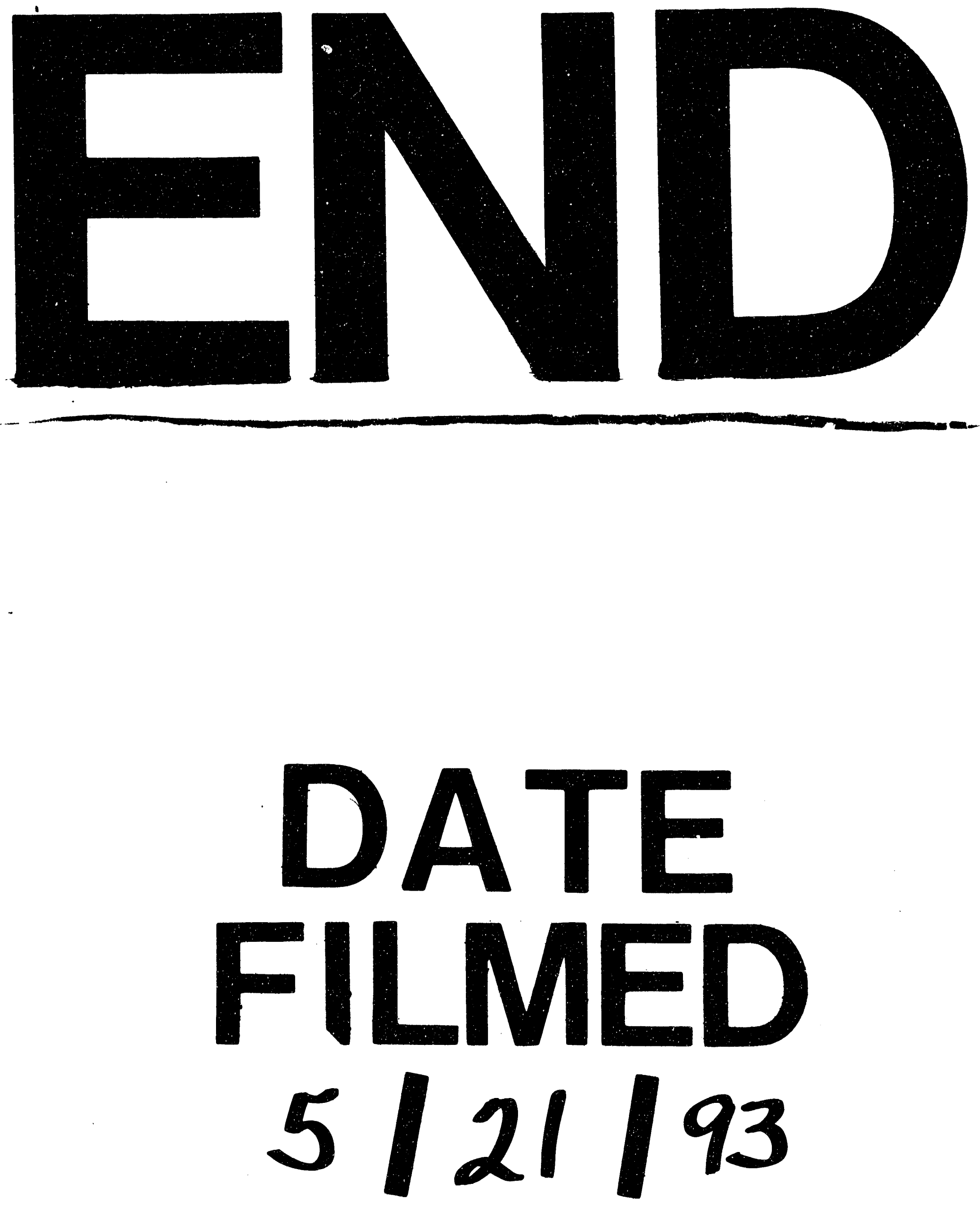
